\title{
Hydrologic Description of the Braden River Watershed, West-Central Florida
}

By M.J. DelCharco and B.R. Lewelling

U.S. Geological Survey

Open-File Report 96-634

Prepared in cooperation with

CITY OF BRADENTON PUBLIC WORKS DEPARTMENT

MANATEE COUNTY ENVIRONMENTAL MANAGEMENT DEPARTMENT

SOUTHWEST FLORIDA WATER MANAGEMENT DISTRICT

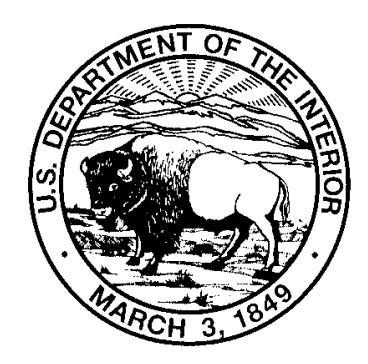

Tallahassee, Florida 


\title{
U.S. DEPARTMENT OF THE INTERIOR BRUCE BABBITT, Secretary
}

\author{
U.S. GEOLOGICAL SURVEY \\ Gordon P. Eaton, Director
}

Any use of trade, product, or firm names in this publication is for descriptive purposes only and does not imply endorsement by the U.S. Geological Survey

$\begin{array}{ll}\begin{array}{l}\text { For additional information } \\ \text { write to: }\end{array} & \begin{array}{l}\text { Copies of this report can be } \\ \text { purchased from: }\end{array} \\ \begin{array}{l}\text { District Chief } \\ \text { U.S. Geological Survey }\end{array} & \text { U.S. Geological Survey } \\ \text { Suite } 3015 & \text { Branch of Information Services } \\ 227 \text { N. Bronough Street } & \text { Box } 25286 \\ \text { Tallahassee, FL } 32301 & \text { Denver, CO 80225-0286 } \\ & \text { Phone: } 800 \text {-USA-MAPS }\end{array}$




\section{CONTENTS}

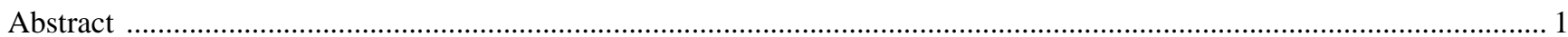

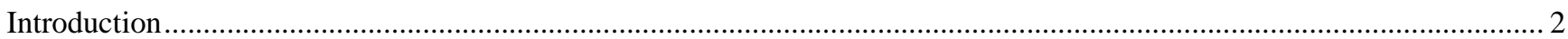

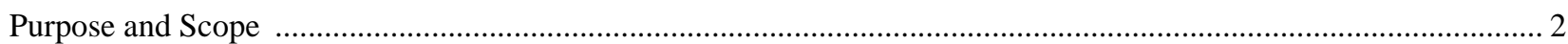

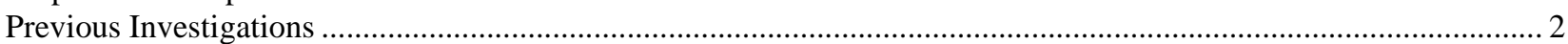

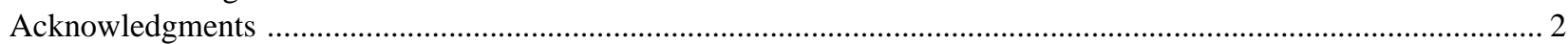

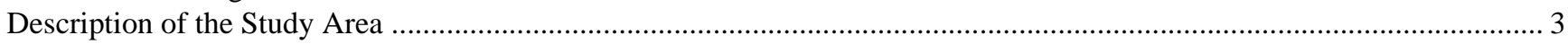

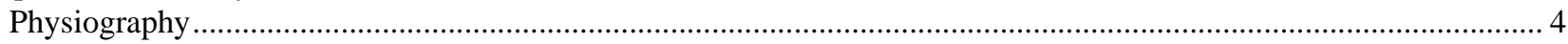

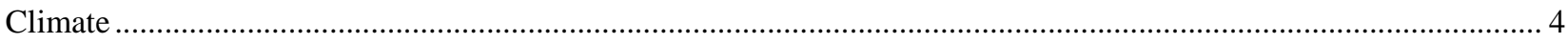

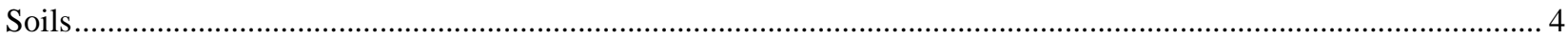

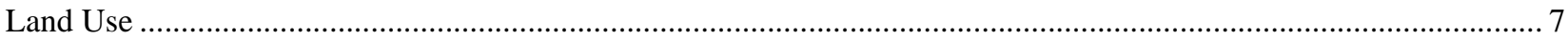

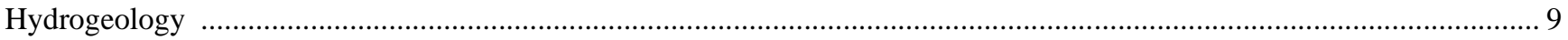

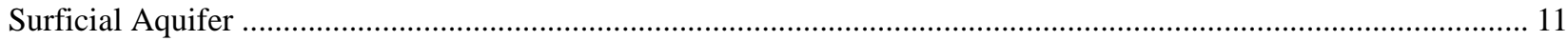

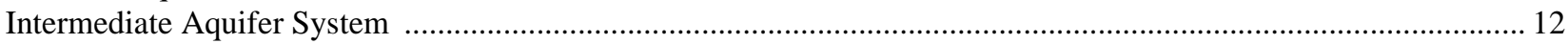

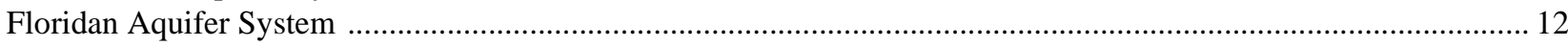

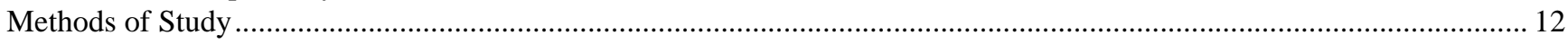

Surface Drainage and Gage Network ............................................................................................................ 17

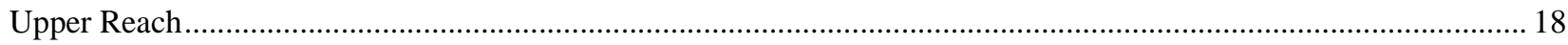

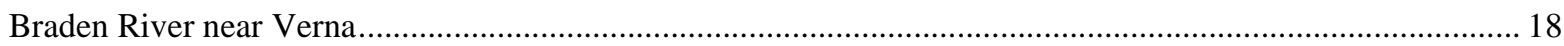

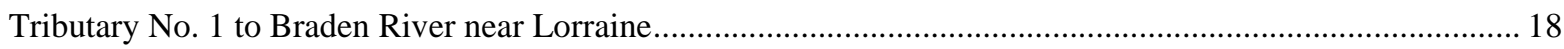

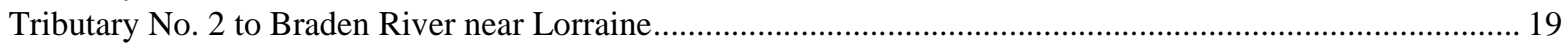

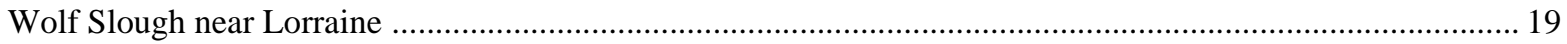

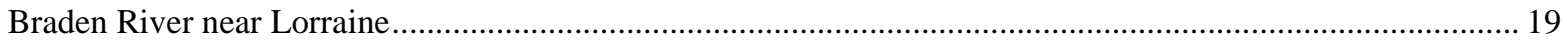

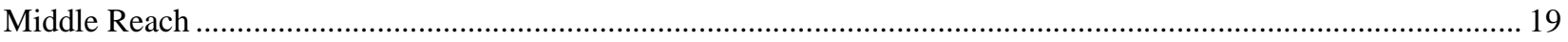

Hickory Hammock Creek near Lorraine ............................................................................................ 19

Cooper Creek at University Parkway near Sarasota …................................................................................ 20

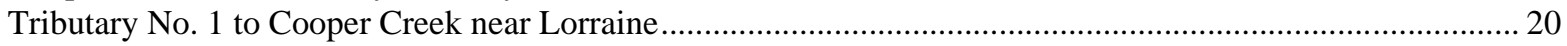

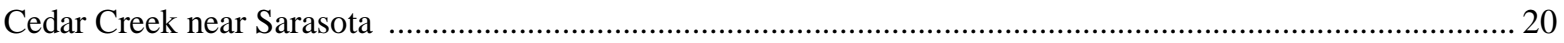

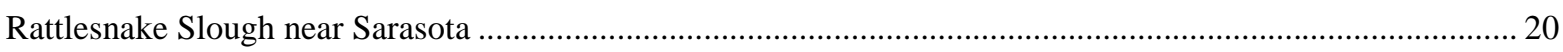

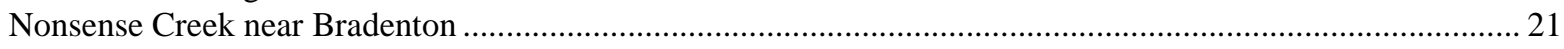

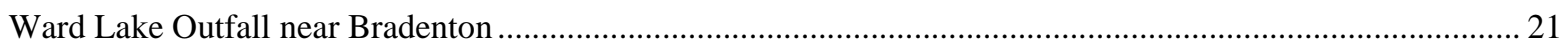

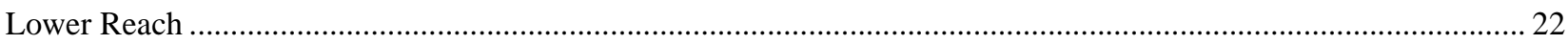

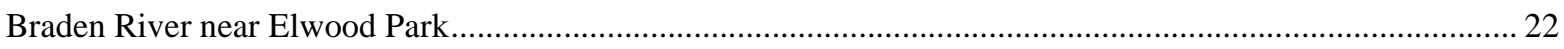

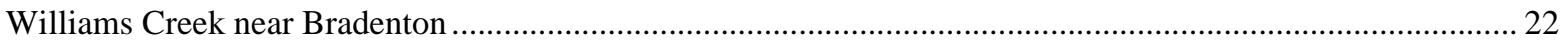

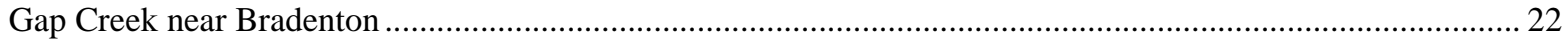

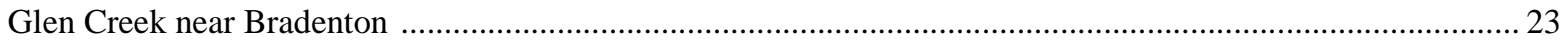

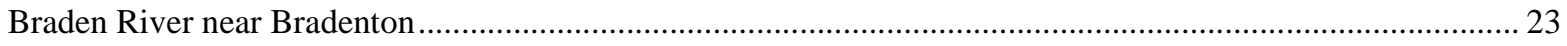

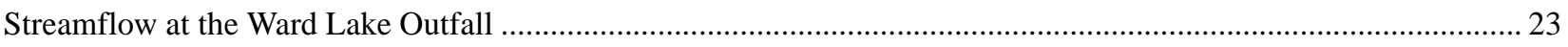

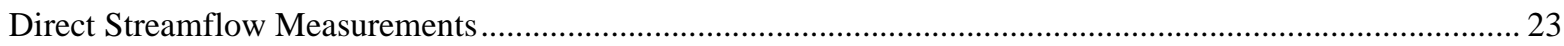

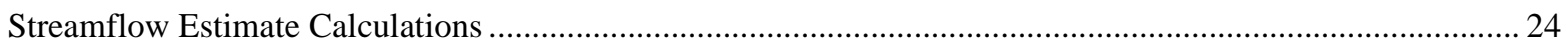

Seepage and Leakage Studies ............................................................................................................... 27

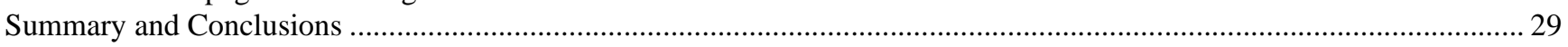

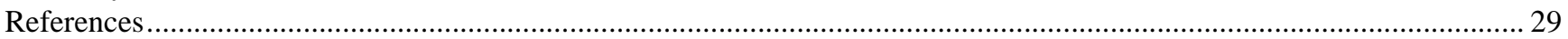

\section{Figures}

1-3. Maps showing:

1. Location of the study area in west-central Florida, showing upper, middle, and lower reaches of the

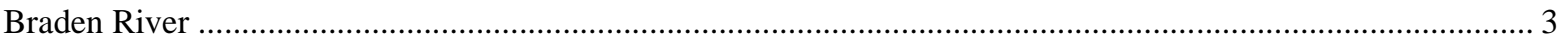

2. Physiographic zones of the Braden River watershed ................................................................................. 5

3. Braden River watershed drainage network and depressional features ............................................................. 6

4. Graph showing average monthly rainfall percentage within the Braden River watershed, 1954-93 ........................ 7

5-10. Maps showing:

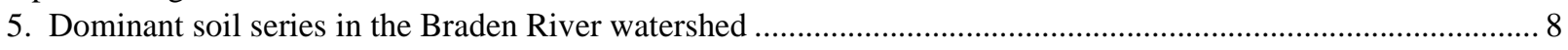

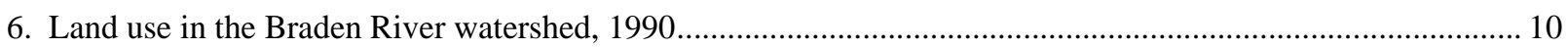


7. Hydrogeologic section A-A' in southwestern Florida

8. Areas of potential flow at land surface from wells open to the Upper Floridan aquifer ................................... 13

9. Location of gaging stations and subbasins in the Braden River watershed ........................................................ 15

10. Aerial view of Ward Lake Outfall and piezometer network ....................................................................... 17

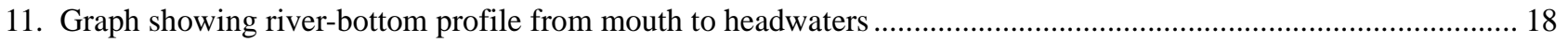

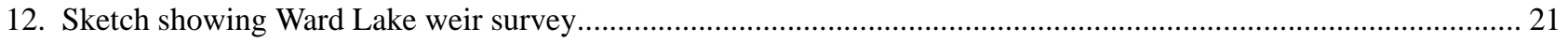

13-16. Graphs showing:

13. Rating curve for Ward Lake Outfall near Bradenton .................................................................................. 24

14. Flow duration curve for Ward Lake Outfall, water years 1993-94 ................................................................. 25

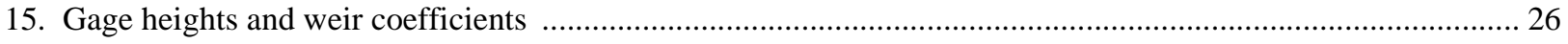

16. Mean, maximum, and minimum water levels in piezometers at Ward Lake Outfall ........................................ 27

\section{Tables}

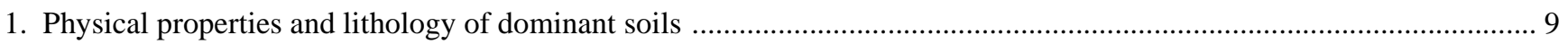

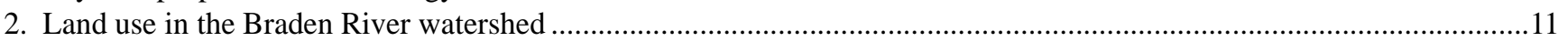

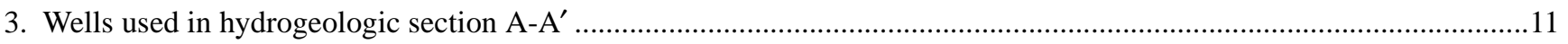

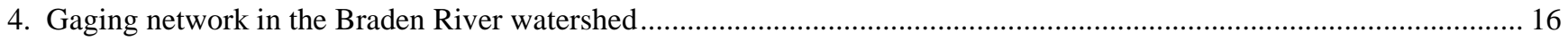

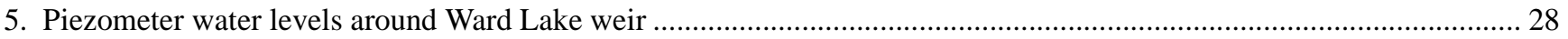

\section{Conversion Factors, Vertical Datum, and Additional Abbreviations}

\begin{tabular}{rll}
\hline Multiply inch-pound unit & \multicolumn{1}{c}{ By } & To obtain \\
\hline inch (in.) & 25.40 & millimeter \\
inch per year (in/yr) & 25.40 & millimeter per year \\
foot (ft) & 0.3048 & meter \\
foot per second $(\mathrm{ft} / \mathrm{s})$ & 0.3048 & meter per second \\
foot per mile $(\mathrm{ft} / \mathrm{mi})$ & 0.3048 & meter per mile \\
mile $(\mathrm{mi})$ & 1.609 & kilometer \\
foot squared $\left(\mathrm{ft}^{2}\right)$ & 0.0929 & square meter \\
cubic foot per second $\left(\mathrm{ft}^{3} / \mathrm{s}\right)$ & 0.02832 & cubic meter per second \\
cubic foot per second per year $\left[\left(\mathrm{ft}^{3} / \mathrm{s}\right) / \mathrm{yr}\right]$ & 0.02832 & cubic meter per second per year \\
gallon $(\mathrm{gal})$ & 3.785 & liter \\
million gallons per day $(\mathrm{Mgal} / \mathrm{d})$ & 0.4381 & cubic meter per second \\
\hline
\end{tabular}

Temperature can be converted between degrees Fahrenheit $\left({ }^{\circ} \mathrm{F}\right)$ and degrees Celsius $\left({ }^{\circ} \mathrm{C}\right)$ as follows:

$$
\begin{gathered}
{ }^{\circ} \mathrm{F}=9 / 5\left({ }^{\circ} \mathrm{C}\right)+32 \\
{ }^{\circ} \mathrm{C}=5 / 9\left({ }^{\circ} \mathrm{F}-32\right)
\end{gathered}
$$

Sea level: In this report "sea level" refers to the National Geodetic Vertical Datum of 1929 (NGVD of 1929) - a geodetic datum derived from a general adjustment of the first-order level nets of the United States and Canada, formerly called Sea Level Datum of 1929.

\section{Additional Abbreviations}

$\begin{aligned} \text { CSI } & =\text { Crest-stage indicator } \\ \text { NOAA } & \text { National Oceanic and Atmospheric Administration } \\ \text { PVC } & =\text { Polyvinylchloride } \\ \text { ROMP } & =\text { Regional Observation Monitor Well Program } \\ \text { SWFWMD } & \text { Southwest Florida Water Management District } \\ \text { USGS }= & \text { U.S. Geological Survey }\end{aligned}$




\title{
Hydrologic Description of the Braden River Watershed, West-Central Florida
}

\author{
By M.J. DelCharco and B.R. Lewelling
}

\section{Abstract}

The Braden River watershed drains an 83-square mile area in west-central Florida and is the largest tributary to the Manatee River. The hydrology of the Braden River was altered in 1936 when the city of Bradenton created Ward Lake, a reservoir with an 838-foot broad-crested weir 6 miles upstream from the mouth. In 1985 the reservoir, which is the sole source of drinking water for the city of Bradenton, was expanded and supplies an annual average of 5.7 million gallons of water per day. The Braden River can be hydrologically divided into three distinct sections that include an 8.6-mile reach of naturally incised, free-flowing channel; a 6.4-mile reach of impounded river created by the Ward Lake reservoir and weir; and a 6-mile reach of tidal estuary. Ten first-order and two second-order tributaries that flow into the Braden River were examined in this report.

The Braden River watershed is dominated by low topographic relief. The two physiographic zones that contain the Braden River watershed, the Gulf Coast Lowlands and De Soto Plain, are both poorly drained and have numerous depressional features. The climate is subtropical with an annual average rainfall of 56 inches, annual average temperatures of 72 degrees Fahrenheit, and estimated annual lake evaporation of 52 inches. The soil series in the watershed are predominantly Myakka-Cassia and the EauGallie-Floridana; these series are characterized as nearly level and poorly drained soils. Land use within the water- shed is the fastest changing characteristic that affects the hydrology of the system. The western half of the watershed is typically urban and includes parts of the city of Bradenton. Land use in the eastern half of the watershed is predominantly agricultural, but the explosive population growth of the area is driving the development of medium to high-density residential communities.

The three major aquifers underlying the Braden River watershed are the surficial, intermediate, and Floridan aquifer systems. The surficial aquifer generally is underlain in places by a clay layer that enhances the ground-water flow of the surficial aquifer to surface-water bodies. The intermediate aquifer system has discontinuous water-bearing units, but retards ground-water movement between the surficial and Floridan aquifer system. The Floridan aquifer system consists of the Upper and Lower Floridan aquifers separated by a middle confining unit. The Upper Floridan aquifer is the primary source for groundwater withdrawals in the watershed and has, at times, heads 20 feet higher than land-surface elevation.

Discharge over the Ward Lake weir into the tidal estuary was measured using volumetric and standard discharge measurement techniques. Annual mean flow for water years 1993 and 1994 were 59.7 and 57.3 cubic feet per second, respectively. Weir coefficients, calculated from discharge measurements, ranged from 0.023 to 2.99 , depending on the head of water over the weir, and the method of determining length of flow on the weir. 
Weir coefficients calculated from the theoretical rating ranged from 0.032 to 3.11 . No significant seepage was found around the ends of the weir, and no leakage was detected through the weir.

\section{INTRODUCTION}

The Braden River is the source of water supply for Bradenton, a city with a population of 46,600 people in west-central Florida (University Press of Florida, 1994). The population of west-central Florida has increased substantially, and the demand for land and water has increased accordingly. Population growth, and subsequent land development, is expected to continue. Changing land-use patterns, due to increased development, will affect the hydrology of the Braden River watershed by altering the runoff characteristics. While the population and water-supply needs have increased, so has the awareness of potential environmental stresses that result from modifying the volume of freshwater flow to estuarine systems. It is necessary to identify and evaluate the physical characteristics that influence the hydrology of the watershed for future water-resource development and planning.

\section{Purpose and Scope}

The purpose of this report is to: (a) provide a general hydrologic description of the watershed; (b) identify ground- and surface-water contributions of flow to the Braden River; (c) describe the data collection network established to monitor surface drainage in the Braden River watershed, and; (d) present results of a preliminary investigation to measure streamflow at the Ward Lake Outfall, including surface flow and subsurface seepage. This study was conducted in cooperation with the City of Bradenton Public Works Department, Manatee County Environmental Management Department, and the Southwest Florida Water Management District (SWFWMD).

\section{Previous Investigations}

Many of the previous investigations that have been conducted in the Braden River watershed have addressed local effects of specific developments or involved limited assessments of the hydrologic systems. Geraghty and Miller (1977) investigated the ground-water resources of the Palm Aire development in the central part of the watershed using existing hydrologic and geologic information. Brown (1983) investigated the geology, hydrology, and water quality of Manatee County and described water-resource development and water use for the county. Brown also described general land use within the county. Conservation Consultants, Inc. (1983) described the waterquality condition of Ward Lake prior to reconstruction of its weir, and provided estimates of flow over the weir using theoretical weir coefficients. During the expansion of Ward Lake, Camp, Dresser, and McKee (1985) studied the land use and land cover in the Braden River watershed upstream of the weir for a stormwater management plan. Recognizing the need for a comprehensive watershed study, the Tampa Bay Regional Planning Council (1986) used existing studies and data to characterize the watershed with an emphasis on water quality. Wanalista (1989) characterized the watershed upstream of the dam, provided a volume mass balance for the reservoir and developed stormwater management criteria. Wanalista also provided estimates for annual streamflow over the weir by using drainage area and discharge ratios for nearby watershed basins.

\section{Acknowledgments}

The authors gratefully acknowledge the cooperation and assistance from personnel with the city of Bradenton, Manatee County, and the Southwest Florida Water Management District. Special thanks are given to Earl Crawley and William Taylor, Bradenton Public Works Department, for their many contributions to the study. Thanks to Bradenton personnel at the water treatment plant, Keith McGurn and Clyde Crews, who helped to keep the gages in good order. Thanks also to the Bradenton Public Works crews who helped construct a gage at the weir and who helped keep the weir clear of debris. Special thanks are given to Robert Brown and Greg Blanchard of the Manatee County Environmental Management Department who contributed to the study and maintained access paths to several of our gaging stations. Thanks are also extended to Roger Hill, with the Schroder-Manatee Ranch, for authorizing access to ranch property and permission to install several streamflow gaging stations and monitor wells. In addition, thanks to Wayne Rilko, of Quality Aggregates Inc., for providing information on hydraulic properties and drilling records of selected surficial aquifer wells. 


\section{DESCRIPTION OF THE STUDY AREA}

The Braden River is a tributary of the Manatee River, which empties into Tampa Bay on the gulf coast of Florida (fig. 1). Ward Lake is an impoundment on the Braden River that is the sole water supply for the city of Bradenton. The lake was formed in 1936 when the river was dammed with a weir structure, named the John Ward Dam. Ward Lake was enlarged by expanding the reservoir and reconstructing the weir in 1985 to assure an annual average supply of $5.7 \mathrm{Mgal} / \mathrm{d}$ for the city. Bradenton's current withdrawal permit for the reservoir is for an annual average of $5.7 \mathrm{Mgal} / \mathrm{d}$, a monthly peak of $6.5 \mathrm{Mgal} / \mathrm{d}$, and a maximum daily withdrawal of $8.2 \mathrm{Mgal} / \mathrm{d}$. The water treatment plant is designed to withdraw in excess of $6 \mathrm{Mgal} / \mathrm{d}$. The Bradenton City Council renamed Ward Lake the Bill Evers Reservoir in 1985. This report will use the name Ward Lake for the reservoir and Ward Lake weir or Outfall for the John Ward Dam. The surface area of the lake was enlarged from 167 to 359 acres by dredging the channel and the surrounding riverbank upstream of the weir (Tampa Bay Regional Planning Council, 1986).
Downstream from the 838-ft wide Ward Lake weir, the Braden River is a coastal plain estuary that is brackish and tidally influenced. Salinity in the tidal reach is affected by the amount of freshwater discharging over the weir, by tributaries that flow directly into the reach from nearby drainage basins downstream of the weir, and by upstream migration of brackish waters from the Manatee River and Tampa Bay. Water-supply withdrawals from the lake are regulated by the SWFWMD. The SWFWMD is concerned that withdrawals from the reservoir are decreasing freshwater discharges to the estuary.

The study area generally is urban near the western watershed boundary, but consists of agricultural land and rangelands in the east. Physical aspects, such as climate and soils, affect hydrology in the watershed though they remain relatively constant; however, other aspects that also affect hydrology, such as land use, can change rapidly.

Approximately 90 percent of the Braden River watershed is in Manatee County, with the remaining 10 percent in northern Sarasota County. The $83-\mathrm{mi}^{2}$ watershed extends south-southeast from the Manatee

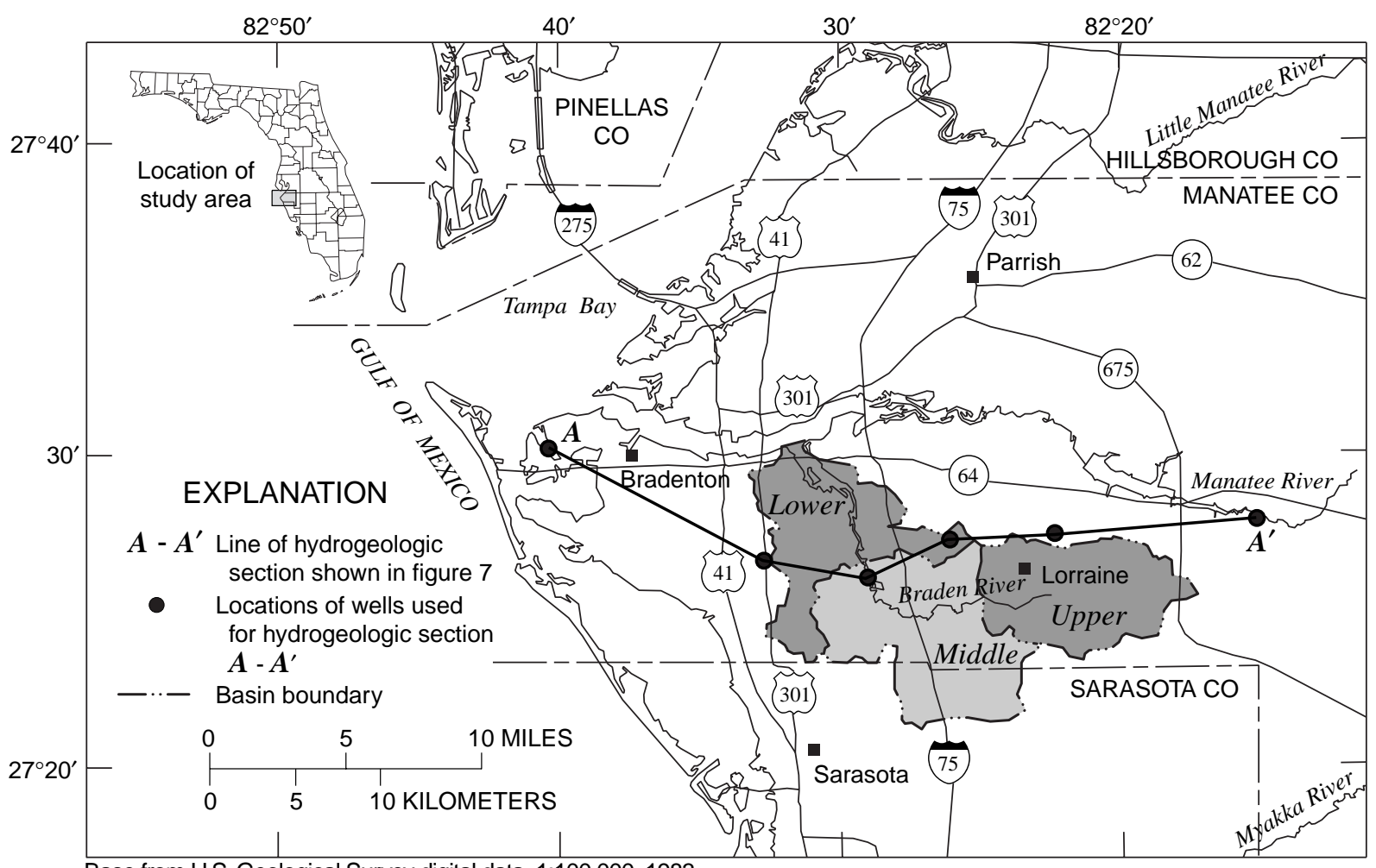

Base from U.S. Geological Survey digital data, 1:100,000, 1983

Albers Equal-Area Conic projection

Standard Parallels $29^{\circ} 30^{\prime}$ and $45^{\circ} 30^{\prime}$, central meridian $-83^{\circ} 00^{\prime}$

Figure 1. Location of the study area in west-central Florida, showing upper, middle, and lower reaches of the Braden River. 
River. Braden River is the largest tributary to the Manatee River, encompassing 24 percent of its 345- $\mathrm{mi}^{2}$ drainage area. The confluence of the Braden and Manatee Rivers is about $7 \mathrm{mi}$ upstream from the mouth of the Manatee River at Tampa Bay.

\section{Physiography}

The Braden River watershed generally is characterized by low topographic relief. Land-surface elevations range from about $100 \mathrm{ft}$ above sea level at the headwaters, along the eastern boundary of the watershed, to sea level along the gulf coast to the west. Land-surface elevations within the western half of the watershed are approximately $25 \mathrm{ft}$ or less above sea level. Near the Braden River mouth, land surface commonly is less than $15 \mathrm{ft}$ above sea level.

The Braden River watershed lies within the midpeninsular physiographic zones described by White (1970) as the Gulf Coastal Lowlands and De Soto Plain (fig. 2). These subdivisions correspond approximately to several marine plains or terraces that were formed by invasions of the sea during the Pleistocene Epoch. The relatively flat, poorly drained Gulf Coastal Lowlands include the Pamlico Terrace, generally less than $25 \mathrm{ft}$ above sea level, and the Talbot Terrace, about 25 to $40 \mathrm{ft}$ above sea level. The Penholoway Terrace, about 40 to $70 \mathrm{ft}$ above sea level, and the Wicomaco Terrace, about 70 to $90 \mathrm{ft}$ above sea level, compose the De Soto Plain along the eastern boundary of the Braden River watershed (Brown, 1983). The land surface in these two subdivisions is poorly drained and has numerous marshes, many in saucer-like depressions ( fig 3). Areas of the watershed, mainly in the eastern half, have been channelized to accelerate natural drainage from areas that previously experienced temporary flooding during periods of average rainfall.

\section{Climate}

Climate in the study area is subtropical and is characterized by high average annual rainfall and temperatures. Monthly humidities average more than 70 percent. Intense rainfall, generated by localized convective thunderstorm activity from June through September, accounts for about 62 percent of the annual rainfall. Periodic cold fronts account for most of the rainfall from December through March (fig. 4). From
June to November, heavy rainfall associated with tropical storms and hurricanes can affect the study area. An intense tropical storm during June 24-30, 1992, produced $16.95 \mathrm{in}$. of rainfall within the watershed (National Oceanic and Atmospheric Administration (NOAA), 1992) and resulted in widespread flooding. In the Braden River watershed, this amount of rainfall produced over a 7-day period is categorized as a 25-year storm (U.S. Department of Commerce, Weather Bureau, 1964).

A long-term NOAA reporting weather station is located at the Gulf Coast Research and Education Center for the Institute of Food and Agricultural Sciences of the University of Florida, and is located within the Braden River watershed about 0.5 mi north of Ward Lake. Meteorological data have been collected at this site since 1965 and, previously, at a location about $5 \mathrm{mi}$ west of the present site from 1954-65. Meteorological data collected include: air temperature, rainfall, total accumulated solar radiation, wind speed and direction, humidity, and daily pan evaporation. Based on the 40-year period of record from 1954-93, the annual rainfall averages $56.0 \mathrm{in}$. and annual air temperature averages $72^{\circ} \mathrm{F}$ (NOAA, 1993). A second long-term weather reporting station also is located nearby at the Sarasota-Bradenton Airport, about $2 \mathrm{mi}$ west of the watershed. Evapotranspiration in Manatee County is estimated to be about $39 \mathrm{in} / \mathrm{yr}$ (Cherry and others, 1970). This estimate is computed from a water-balance difference between rainfall (56 in.) and surface runoff (18 in., calculated from six basins) plus ground-water recharge (about 1 in.). Average annual lake evaporation is estimated to be about 52 in. (Kohler and others, 1959, p. 2), and evapotranspiration from the numerous predominant wet-weather vegetation-filled ponds in the area could exceed 60 in. a year (Joyner and Sutcliffe, 1976).

\section{Soils}

Detailed soil survey information can indicate certain hydrologic conditions of an area, such as the runoff and drainage characteristics, and also can indicate the hydraulic conductivity of the surficial aquifer. The Natural Resources Conservation Service (formerly, Soil Conservation Service) of the U.S. Department of Agriculture (1983) has identified six 


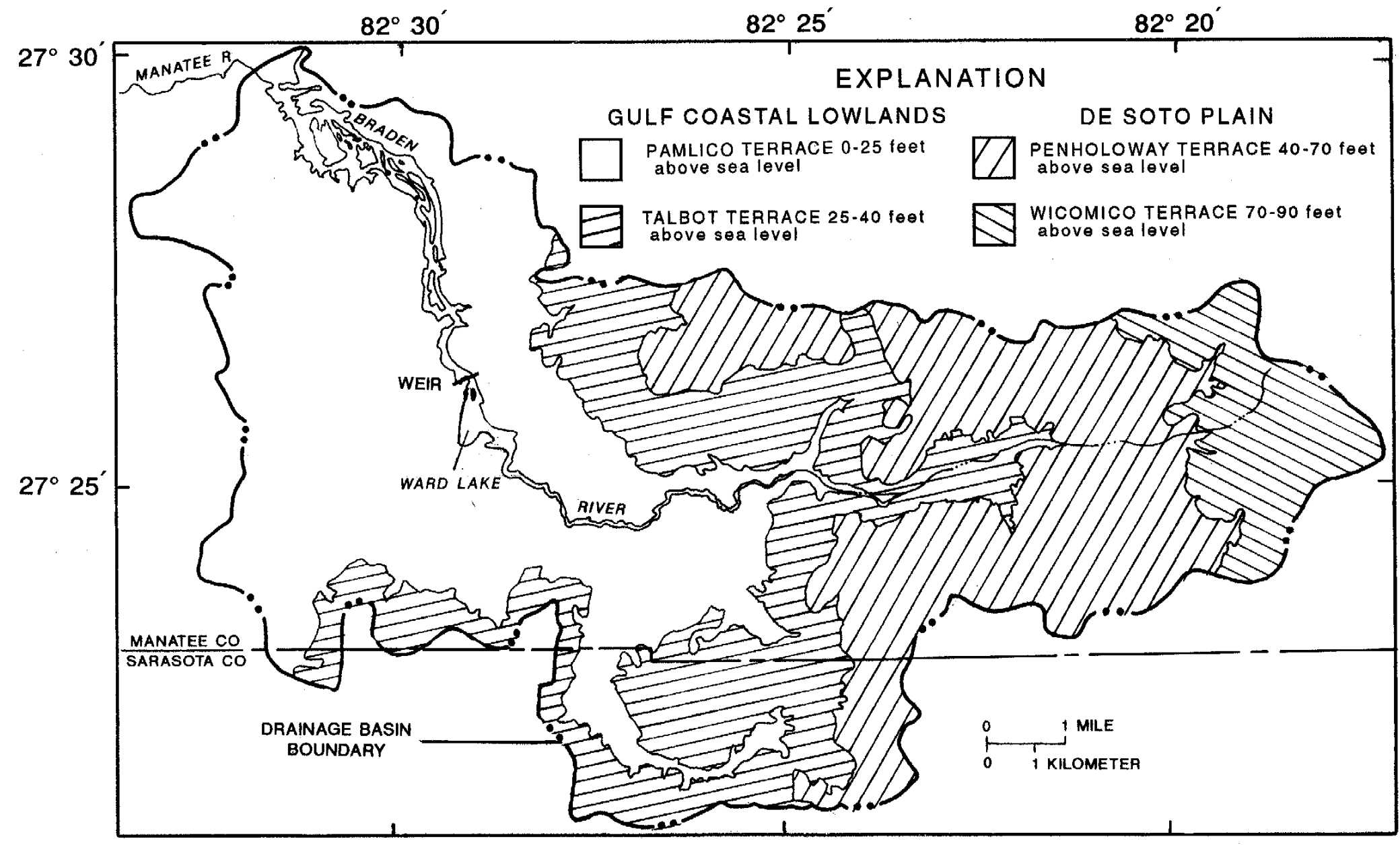

Figure 2. Physiographic zones of the Braden River watershed. 


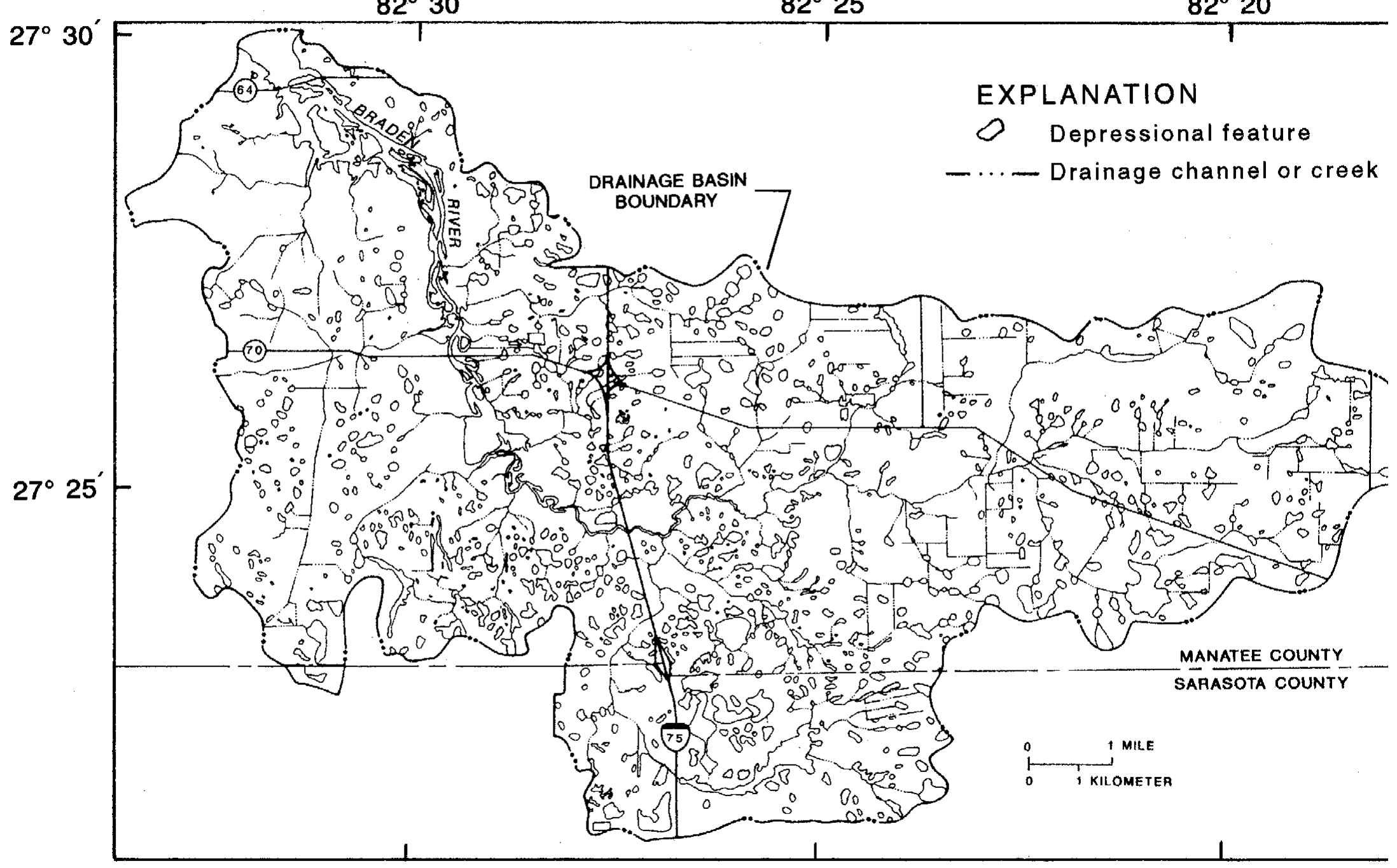

Figure 3. Braden River watershed drainage network and depressional features. 


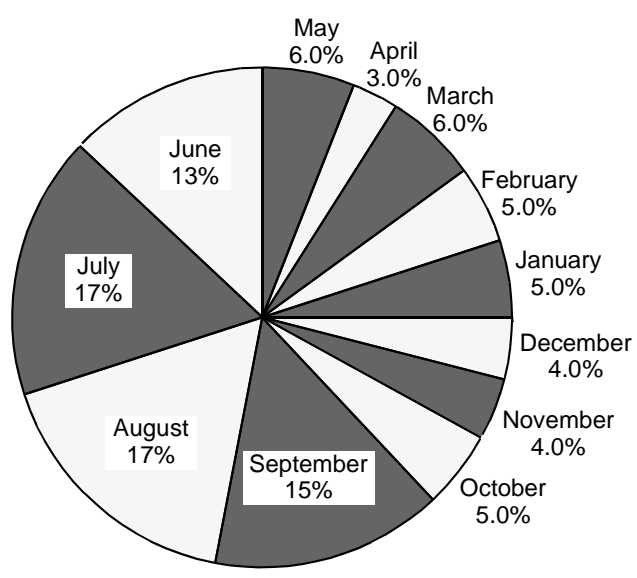

Figure 4. Average monthly rainfall percentage within the Braden River watershed, 1954-93.

general soil series in the Braden River watershed (fig. 5). Each soil series is a group of two or three soil types that have profiles similar in composition, thickness, and arrangement yet have differences in relative proportions of sand, silt, and clay of the surface layer or underlying material. Soil series are classified by naming the most prevalent soil type first, followed by soil types having smaller percentages. The physical characteristics of each soil series, such as slope, drainage, permeability, depth to water table, saturation, and stratigraphy, determine the efficiency of the watershed to facilitate runoff, interflow, and recharge.

The dominant two soil series in the Braden River watershed are the Myakka-Cassia and the EauGallieFloridana. The Myakka-Cassia series is prevalent in the eastern half of the watershed, whereas the EauGallie-Floridana series is prevalent in the western half of the watershed. Both series are characterized as nearly level, poorly drained soils of moderate to rapid permeability, formed in sandy marine deposits, and are found mainly in flatwoods. The permeability of these soils is similar but varies with depth and clay content (table 1). Depth to water table typically ranges from 10 to $40 \mathrm{in}$. below land surface. The Myakka-Cassia series can be further characterized as underlain by shells and shell fragments in places. The Floridana soils make up a small part of both series and occur in the numerous depressions and low flat areas throughout the watershed. This soil is poorly drained and has low permeability on low gradient terrain. The Floridana soils create hard-pan features that function as depressional wetlands and probably are not connected to ground-water sources (Juan Vega, Natural Resources Conservation Service, oral commun., 1995). Other major soil types in the watershed are: Wabasso-Bradenton-EauGallie; Delray-Floridana; Okeelanta; Felda-Wabasso. These soil types have similar characteristics to those previously discussed, being nearly level and poorly drained sandy soils.

The permeability of soils in the Braden River watershed is a major factor in determining the extent of surface and ground-water interaction. Although the overall permeability of the dominant soil types in the watershed is moderate to rapid, drainage remains poor because of underlying soil horizons with low permeability. For example, the Cassia soil type is moderate to highly permeable in the top $24 \mathrm{in}$. and below about 33 in., but has a very low permeability between 25 and 33 in. below land surface. It is this layer, or horizon, of low-permeable soil which helps to create a poorly drained soil. Other characteristics that encourage poorly drained soils are the low topographic relief of the area, and underlying clay layers (typically the top of the intermediate aquifer system) that restrict the downward migration of flow in the surficial aquifer. Water percolating through the soil is impeded by these clay layers and thus saturates the overlying soil, creating locally high water-table elevations. Where clay layers exist near the Braden River and its tributaries, rainfall infiltration saturates the soil and discharges into the surface-water systems.

\section{Land Use}

Rapid population growth in Manatee County is indicative of the explosive population growth experienced along the gulf coast of west-central Florida. The population in Manatee County has increased from 148,400 in 1980 to 223,500 (estimated) in 1993 (University Press of Florida, 1994). This accelerated population growth and subsequent development is rapidly changing land-use characteristics within large areas of the Braden River watershed. In the eastern half of the watershed, large tracts of agricultural land and rangelands are being developed into subdivisions of medium to high density single-family homes, golf courses, and commercial centers. Changes in land-use patterns in the watershed can have a significant effect on the hydrology of the watershed. For example, ground-water recharge to the surficial aquifer and surface-water systems can be affected by land-use changes. These changes and their effects on hydrologic systems are difficult to evaluate. 


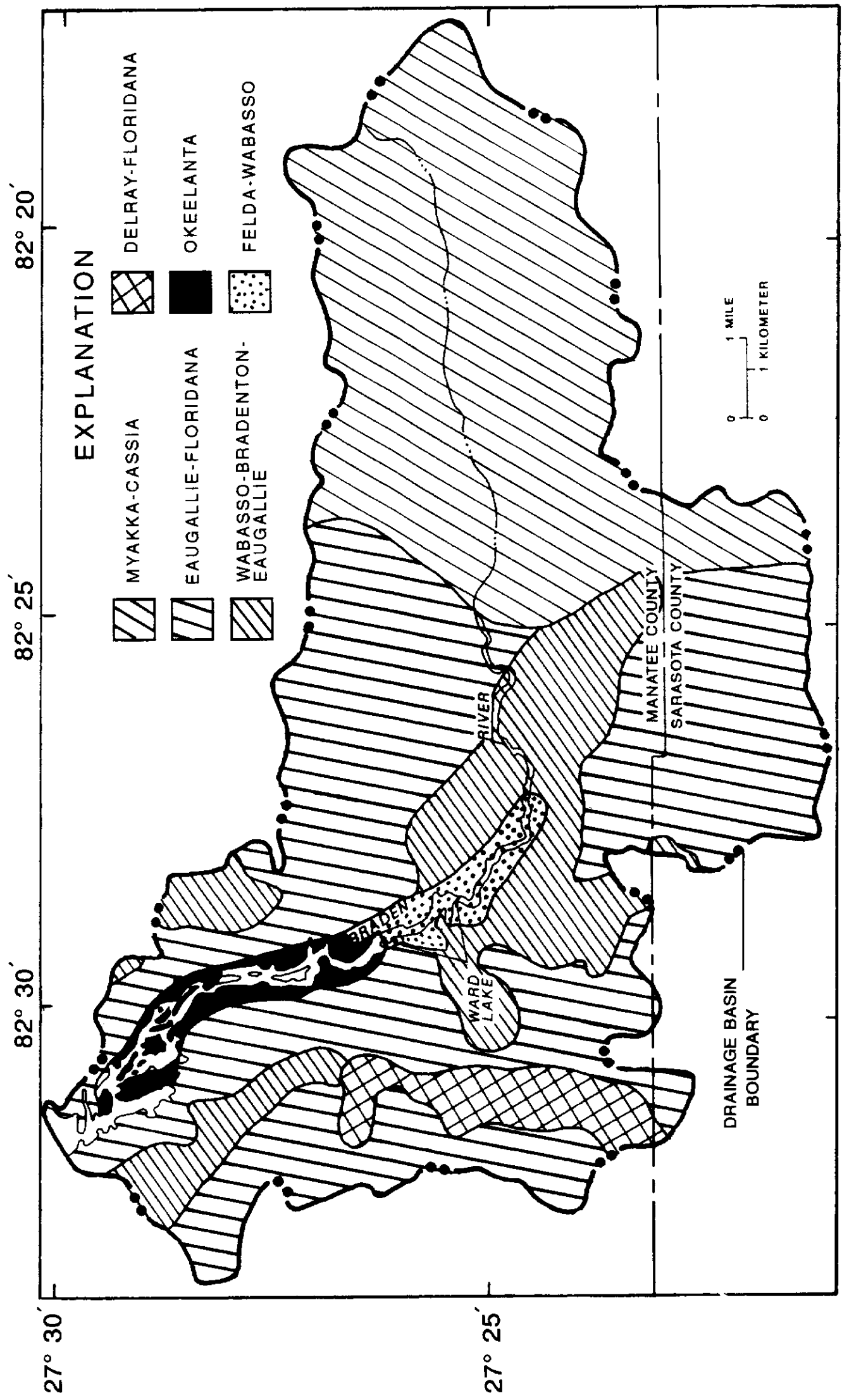

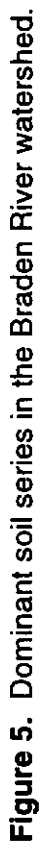


Table 1. Physical properties and lithology of dominant soils

[in., inches; \%, percent; in/h, inches per hour. Modified from Soil Conservation Service, 1983]

\begin{tabular}{|c|c|c|c|c|}
\hline $\begin{array}{l}\text { Soil } \\
\text { type }\end{array}$ & $\begin{array}{c}\text { Depth } \\
\text { (in.) }\end{array}$ & $\begin{array}{c}\text { Clay } \\
(\%)\end{array}$ & $\begin{array}{l}\text { Perme- } \\
\text { ability } \\
\text { (in/h) }\end{array}$ & Lithology \\
\hline Myakka & $\begin{array}{r}0-23 \\
23-37 \\
37-80\end{array}$ & $\begin{array}{l}<2 \\
2-8 \\
<2\end{array}$ & $\begin{array}{r}6.0-20 \\
0.6-6.0 \\
6.0-20\end{array}$ & $\begin{array}{l}\text { fine sand } \\
\text { sand, fine sand, loamy fine } \\
\text { sand } \\
\text { sand, fine sand }\end{array}$ \\
\hline Cassia & $\begin{array}{r}0-24 \\
24-33 \\
33-80\end{array}$ & $\begin{array}{r}1-4 \\
2-10 \\
1-5\end{array}$ & $\begin{array}{r}6.0-20 \\
0.6-6.0 \\
6.0-20\end{array}$ & $\begin{array}{l}\text { fine sand } \\
\text { sand, fine sand, loamy sand } \\
\text { sand, fine sand }\end{array}$ \\
\hline $\begin{array}{l}\text { Eau } \\
\text { Gallie }\end{array}$ & $\begin{array}{r}0-28 \\
28-42 \\
42-50 \\
50-65\end{array}$ & $\begin{array}{r}<5 \\
1-8 \\
13-31 \\
1-13\end{array}$ & $\begin{array}{r}6.0-20 \\
0.6-6.0 \\
0.6-6.0 \\
2.0-6.0\end{array}$ & $\begin{array}{l}\text { fine sand } \\
\text { sand, fine sand } \\
\text { sandy loam, fine sandy } \\
\text { loam, sandy clay loam } \\
\text { sand, loamy sand, loamy } \\
\text { fine sand }\end{array}$ \\
\hline Floridana & $\begin{array}{r}0-19 \\
19-36 \\
36-63\end{array}$ & $\begin{array}{r}3-10 \\
1-7 \\
15-30\end{array}$ & $\begin{array}{r}6.0-20 \\
6.0-20 \\
<0.2\end{array}$ & $\begin{array}{l}\text { fine sand } \\
\text { sand, fine sand } \\
\text { sandy loam, fine sandy } \\
\text { loam, sandy }\end{array}$ \\
\hline
\end{tabular}

Land use within the Braden River watershed ranges from the highly developed urban areas that include parts of Bradenton, to the undeveloped forested lands adjacent to the Braden River. Available information on land use and land cover in the watershed, upstream from Ward Lake, was prepared in a study by Camp, Dresser, and McKee (1985) for the Manatee County Planning and Development Department. In addition, during 1990, the SWFWMD generated land use and land cover maps using color infrared photography for the Braden River watershed (fig. 6). Land-use acreage and percentage of total area for 1985 and 1990 as a result of these studies are presented in table 2 .

Although the watershed is becoming increasingly residential, much of the land remains agricultural, as shown in fig. 6. Agriculture can affect the hydrology of the Braden River watershed in several ways. Irrigation of crops can create artificial recharge resulting in increased base flow to creeks as the irrigation water seeps through the surficial aquifer to a surfacewater body. Pumping of ground water also can result in lowering the water-level elevation in overlying surface-water features, such as streams and lakes. In the eastern half of the watershed, agricultural land and rangeland typically are ditched and channelized to enhance surface-water drainage.

Surface mining accounts for a small percentage of overall land use and is confined to the southcentral part of the watershed. This mining is done to extract sand and shell from surficial deposits; no chemicals are used in the process (Wayne Rilko, Quality Aggregates, Inc., written commun., 1993). Mining activities have altered the natural flow patterns within the Braden River watershed by creating borrow pits and settling ponds. Dewatering of shell pits, which is done intermittently, also can affect both ground-water and surface-water flow.

\section{HYDROGEOLOGY}

The hydrogeologic system in the Braden River watershed area consists of thick sequences of carbonate rocks and clastic sediments which are intermittently hydraulically connected. Principal hydrogeologic units are the surficial, the intermediate, and the Upper Floridan aquifer systems. The surficial aquifer, in places, has discontinuous layers of clay stringers that can restrict vertical groundwater flow. The surficial aquifer also is underlain with a thick clay layer, the top of the intermediate aquifer system, that also can restrict vertical groundwater flow. The Upper Floridan aquifer system is separated from the surficial aquifer by the intermediate aquifer system.

The hydrogeologic section $\mathrm{A}-\mathrm{A}^{\prime}$, shown in figure 7, intersects the Braden River watershed from west to east. The hydrogeologic section A- $\mathrm{A}^{\prime}$ incorporates the lithology from several wells in the Braden River watershed including TR 7-4, a Regional Observation and Monitor Well Program (ROMP) well at the west edge of Ward Lake. The surficial aquifer generally is about $30 \mathrm{ft}$ thick and overlies an intermediate aquifer system confining unit that ranges in thickness from 60 to $140 \mathrm{ft}$. Well descriptions for the wells used to define the hydrogeologic section (Barr, 1996) are presented in table 3. 


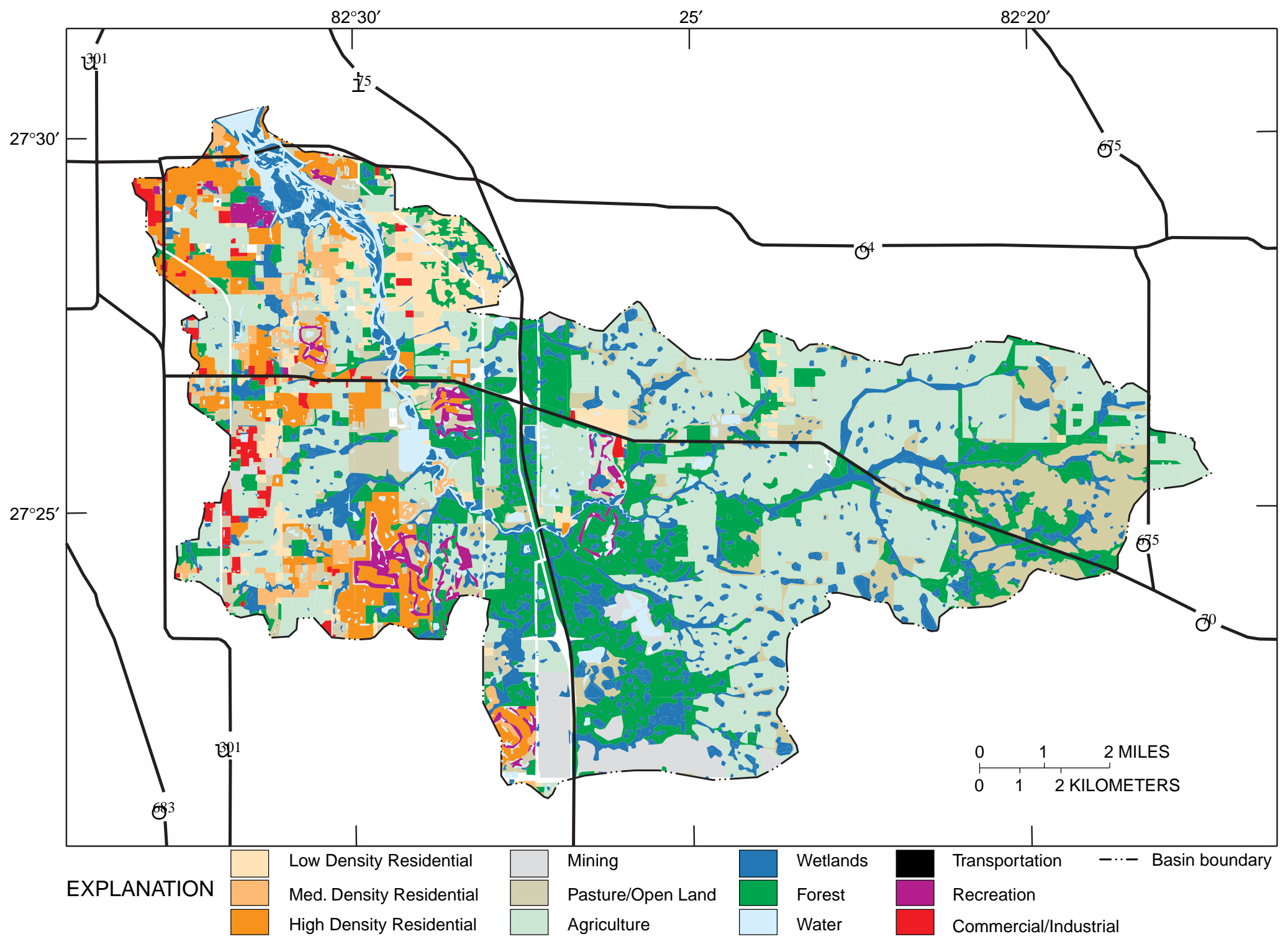

Figure 6. Land use in the Braden River watershed 1990. (From Southwest Florida Water Management District GIS data base.) 
Table 2. Land use in the Braden River watershed

\begin{tabular}{lrr|rr}
\hline & \multicolumn{1}{c|}{$\begin{array}{c}\text { Braden River } \\
\text { watershed } \\
\text { Lpstream of Ward } \\
\text { Lake weir }\end{array}$} & \multicolumn{2}{c}{$\begin{array}{c}\text { 1985 } \\
\text { Land use }\end{array}$} & $\begin{array}{c}\text { Total } \\
\text { Braden River } \\
\text { watershed }\end{array}$ \\
\cline { 2 - 5 } & Acres & $\begin{array}{c}\text { Percent } \\
\text { of total } \\
\text { area }\end{array}$ & Acres & $\begin{array}{c}\text { Percent } \\
\text { of total } \\
\text { area }\end{array}$ \\
\hline Forest & 2,980 & 7.7 & 9,614 & 18.0 \\
Pasture/Open land & 29,108 & 75.4 & 6,094 & 11.4 \\
Recreation & 291 & 0.8 & 915 & 1.7 \\
Agriculture & 1,778 & 4.6 & 17,585 & 32.9 \\
Wetlands & 1,607 & 4.2 & 7,440 & 13.9 \\
Low-density single & 382 & 1.0 & 2,321 & 4.3 \\
$\quad$ family residences & 545 & 1.4 & 1,057 & 2.0 \\
Medium-density single & 549 & & & \\
$\quad$ family residences & 179 & 0.5 & 3,237 & 6.1 \\
High-density residences & 115 & 0.3 & 760 & 1.4 \\
Commercial/Industrial & 1,013 & 2.6 & 1,506 & 2.8 \\
Mining & 244 & 0.6 & 903 & 1.7 \\
Transportation/Utilities & 354 & 0.9 & 2,056 & 3.8 \\
Water & 38,596 & 100.0 & 53,489 & 100.0 \\
\hline Total & & & & \\
\hline
\end{tabular}

${ }^{a}$ Camp, Dresser, and McKee, Inc., 1985, Southeast area stormwater management study: Final Report, 111 p.

${ }^{\mathrm{b}}$ Southwest Florida Water Management District, 1990, GIS data base.

\section{Surficial Aquifer}

The surficial aquifer is the principal hydrologic unit that exchanges water with surface-water systems. The surficial aquifer is contiguous with land surface and consists primarily of unconsolidated sand, clay, shell, and phosphate gravel intermixed with stringers of limestone and marl of Quaternary to Upper Tertiary age (Brown,1983; Barr, 1996). The aquifer generally is unconfined; however, lenses of sand, marl, and limestone contain water under confined conditions in some areas (Hutchinson, 1984). Hydraulic properties of the surficial aquifer are highly variable considering the physical characteristics of the rock and sand matrix, such as grain size, sorting, and thickness. These characteristics influence porosity and permeability thereby affecting the ability of the unit to transmit water (Knochenmus and Thompson, 1991). The hydraulic properties of the surficial sediments can enhance or retard the exchange of water between surface-water bodies and the surficial aquifer.

Sediment deposits of the surficial aquifer are mined along the southern boundary of the Braden River watershed, mainly within the Cooper Creek

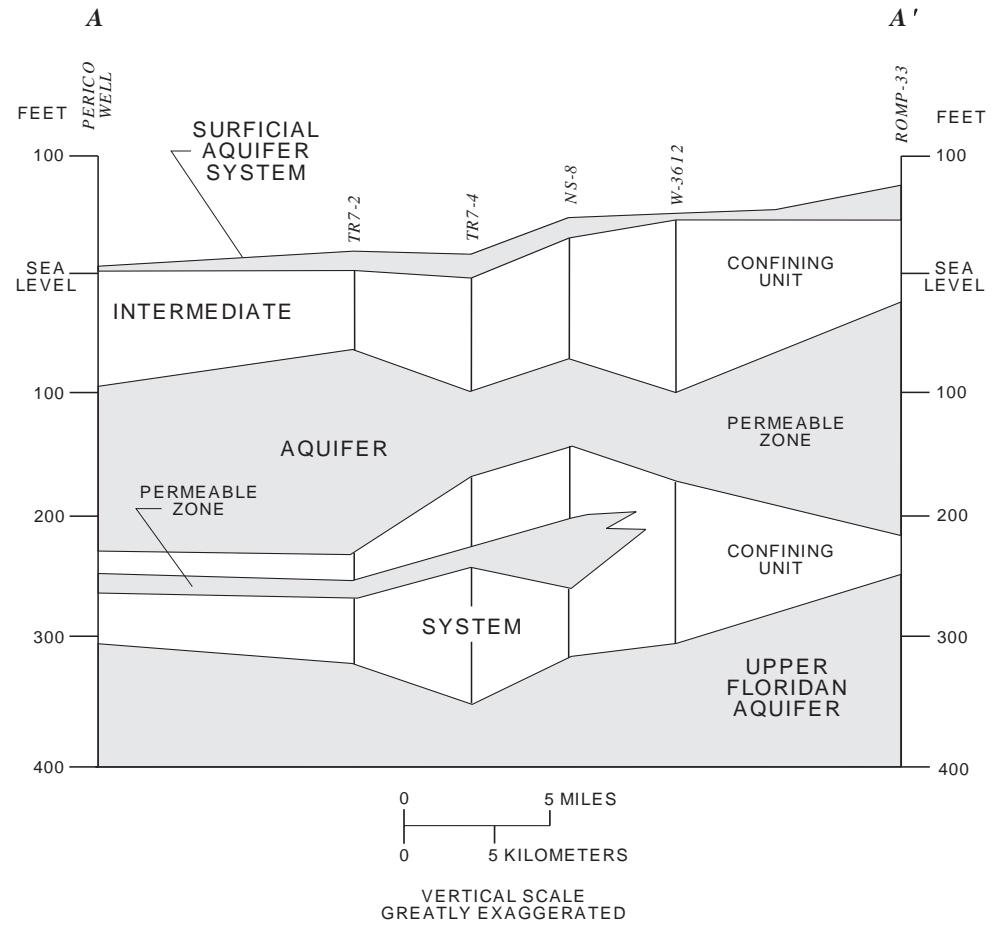

Figure 7. Hydrogeologic section A-A' in southwestern Florida. (Modified from Barr, 1996. Line of section is shown in figure 1.)
Table 3. Wells used in hydrogeologic section $A-A^{\prime}$

[Modified from Barr, 1996]

\begin{tabular}{lcc}
\hline $\begin{array}{c}\text { Well } \\
\text { name } \\
\text { (as shown } \\
\text { in fig. 7) }\end{array}$ & $\begin{array}{c}\text { Site } \\
\text { identification } \\
\text { number }\end{array}$ & $\begin{array}{c}\text { Depth of } \\
\text { well } \\
\text { (in feet } \\
\text { below land } \\
\text { surface) }\end{array}$ \\
\hline Perico Island & 2729490824040 & 595 \\
TR 7-2 & 2726120823301 & 1,075 \\
TR 7-4 & 2725390822920 & 800 \\
MS 8 & 2726510822625 & 800 \\
W-3612 & 2727020822241 & 740 \\
ROMP 33 & 2727280821530 & 675 \\
\hline
\end{tabular}


subbasin (fig. 9). Unconsolidated overburden and the underlying deposits of the clay-shell matrix that form the Caloosahatchee Formation occur at depths of 20 to $30 \mathrm{ft}$ and are mined for commercial and industrial applications, such as fill and roadbed material and cement aggregate (Wayne Rilko, Quality Aggregates, Inc., oral commun., 1995).

\section{Intermediate Aquifer System}

The intermediate aquifer system includes all water-bearing units and confining units between the overlying surficial aquifer and the underlying Upper Floridan aquifer (Southeastern Geological Society, 1986). The water-bearing units of the intermediate aquifer system consist of discontinuous sand, gravel, shell, and limestone and dolomite beds in the Tamiami Formation of early Pliocene and late Miocene age and the Hawthorn Formation of late and middle Miocene age (Southeastern Geological Society, 1986). The confining units consist of sandy clay, clay, and low to very low permeability carbonate sediments (marl) retarding the vertical movement of ground water between the water-bearing units of the overlying surficial aquifer and the underlying Upper Floridan aquifer (Duerr and others, 1988). However, if the top of the intermediate aquifer system is not confined or if there is a breach in the confining unit, flow might occur from the intermediate water-bearing units to the surficial aquifer or surface-water systems. The altitude of the top of the intermediate aquifer system in the study area ranges from about $40 \mathrm{ft}$ above sea level near the eastern watershed boundary to about sea level from midwatershed westward (fig. 7). The bottom of the intermediate aquifer system (top of the Upper Floridan aquifer) ranges from about $300 \mathrm{ft}$ below sea level at the western watershed boundary to about $250 \mathrm{ft}$ below sea level at the eastern watershed boundary (fig. 7).

\section{Floridan Aquifer System}

The Floridan aquifer system consists of a vertically continuous sequence of Tertiary age carbonate and clastic sediments that are generally hydraulically connected to each other. The permeability of these sediments is several orders of magnitude greater than that of the sediments that bound the system from above and below (Ryder, 1985). The Floridan aquifer system is subdivided into the Upper Floridan aquifer, the middle confining unit, and the Lower Floridan aquifer (Miller, 1986). The middle confining unit and Lower Floridan aquifer generally contain saltwater (Ryder, 1985). The Upper Floridan aquifer is the primary source for ground-water supply in the area; agriculture accounts for most of its use.

When the potentiometric surface of either the Upper Floridan or intermediate aquifer is at or above land surface, the upward movement of water into the surficial aquifer or surface-water bodies is possible. The potentiometric surface is an imaginary surface connecting points where water would rise in a tightly cased well from a given point in the aquifer (Lohman, 1972). Areas within the Braden River watershed where the potentiometric surface of the Upper Floridan aquifer exceeds land surface elevation during typical seasonal periods of low (May) and high (September) water-level conditions are shown in figure 8 . When the potentiometric surface is above land surface, water in wells cased in the Upper Floridan aquifer can flow at land surface. Although the intermediate aquifer system restricts vertical flow between the Upper Floridan and the surficial aquifer, higher potentiometric surface levels in the Upper Floridan aquifer indicate when ground-water has the potential to migrate to the surface-water systems. Water-level measurements by the USGS have ranged from $1.01 \mathrm{ft}$ below to $22.72 \mathrm{ft}$ above sea level at ROMP TR 7-4 Upper Floridan aquifer well, located near the western shore of Ward Lake.

\section{METHODS OF STUDY}

This section describes the data-collection methods used to: (a) characterize surface drainage in the Braden River watershed; (b) measure streamflow at the Ward Lake weir including direct measurement methods, weir coefficient equations, and dischargedrainage area calculations, and; (c) define subsurface flow (seepage) around the ends of the weir and check for leakage through the weir structure.

To characterize the surface drainage of the Braden River watershed, an extensive network of continuous and partial-record streamflow gaging stations was established. A continuous streamflow gaging station records water levels (stage) of the tributary or river. 


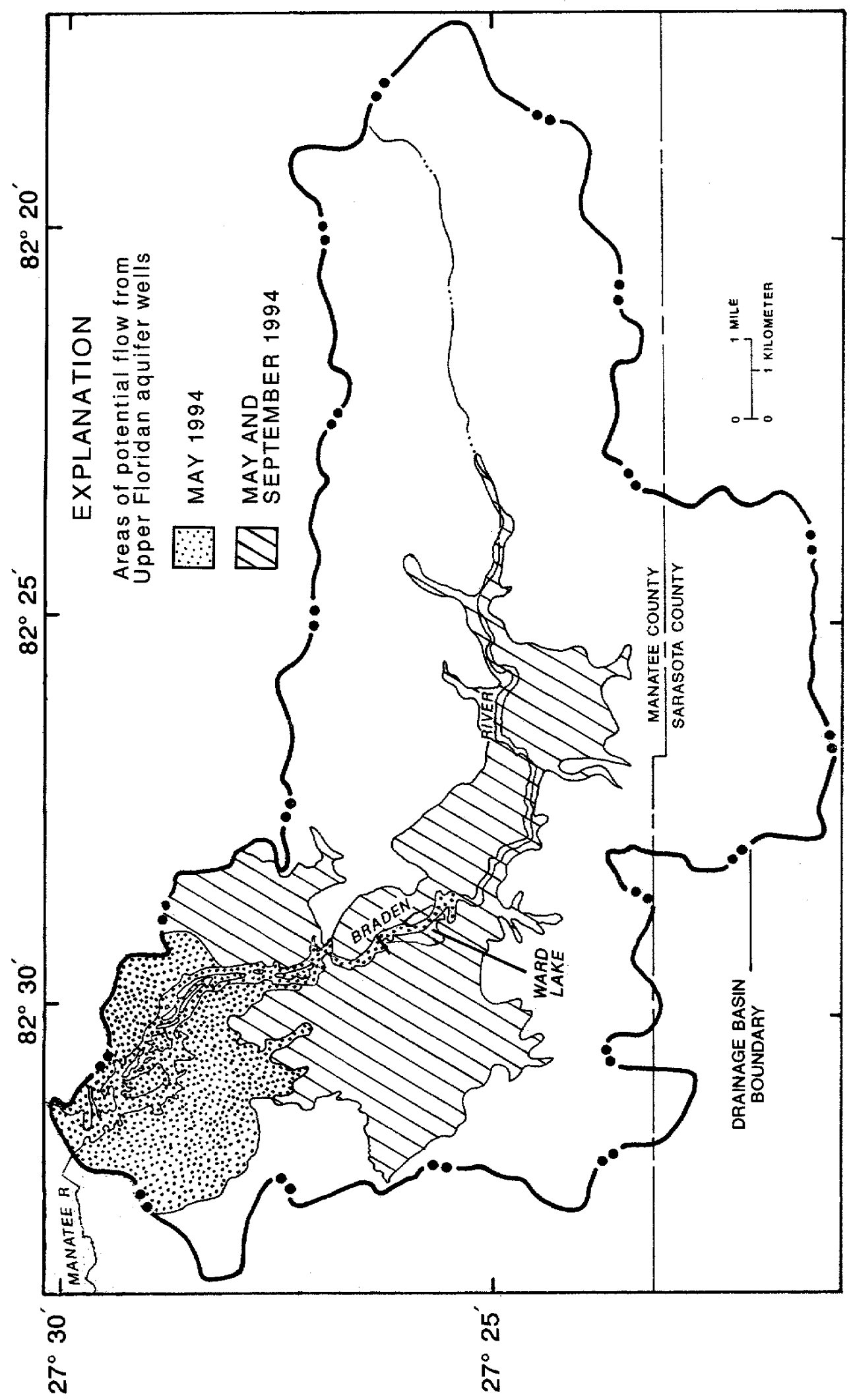

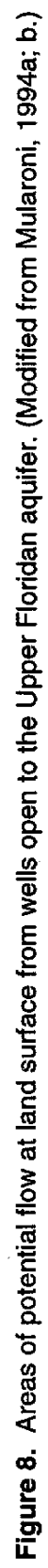


These water levels can be used to compute discharge using a stage/discharge relation developed from a series of discharge measurements. The gaging station network monitors 80 percent of the watershed drainage upstream of the Ward Lake weir and 51 percent of the watershed drainage downstream of the weir. Stations upstream of the Ward Lake weir include gages on eight first-order tributary, one second-order tributary, and two gages on the main-channel of the Braden River. Downstream of the Ward Lake weir, continuous gaging stations were established at two first-order and one second-order tributaries that flow into the tidal reach downstream of Ward Lake and at two tidal sites, one located at the mouth of the Braden River and the other just downstream of the Ward Lake weir. Descriptions of each of the subbasins monitored within the watershed are discussed in downstream order and locations are shown in figure 9 . Table 4 summarizes data for each creek within the subbasins. Discharge computed at each of the main-channel gages is an accumulation of all the flow upstream of that point. The tidal stations record water levels and specific conductance, but are not used to calculate discharge.

All drainage basin boundaries were delineated using USGS topographic maps. Because of the physical limitation associated with accurate ground truthing of contour maps, delineation of the basin and subbasin boundaries are approximations, especially in areas of heavy urban development and places where the land surface has little topographic relief. Also, changes in land use or surface topography, such as agricultural ditching and mining practices, alter flow patterns and make watershed boundaries difficult to distinguish.

To measure streamflow at the Ward Lake weir, a direct measurement method needed to be established. Due to irregularities in the construction of the weir and associated inaccuracies related to theoretical weir flow calculations, a reconnaissance study was initiated to explore the possibility of establishing a direct discharge measurement method. Several different standard measurement methods proved to be successful, dependent upon the volume and velocity of flow over the weir. Direct discharge measurements can be made using volumetric and standard current-meter methods.
A volumetric method of measuring discharge is used during low-flow conditions when the depth of water over the weir is less than or equal to $0.3 \mathrm{ft}$ (about $200 \mathrm{ft}^{3} / \mathrm{s}$ ). Discharge measurements using this method are made by timing the rate needed to fill a container of known volume (Rantz and others, 1982). However, the volumetric method presented here is not a standard volumetric method because it is not feasible to capture all of the flow discharging over the 838-ft-long broadcrested weir. A volumetric method is used to give a discharge per unit width of the weir. In this way, the discharge over the weir can be divided into 20 or more subsections of uniform flow and a volumetric measurement can be made within each subsection, similar to a vertical section in a standard current-meter measurement. To do this, the volumes of different containers are divided by their width to give a volume per foot. The time required to fill an individual container is recorded so that a volume per time (discharge) per foot of width can be calculated. Subsections are generally chosen so that no subsection flow exceeds 5 percent of the total flow. Discharge measurements are made using a combination of both the volumetric and current-meter (pygmy) methods for a range of flow from 200 to $300 \mathrm{ft}^{3} / \mathrm{s}$. Discharge measurements during high-flow conditions (greater than $300 \mathrm{ft}^{3} / \mathrm{s}$ ) are made by boat at a cross section about $250 \mathrm{ft}$ upstream from the weir for improved accuracy and safety. Flow measurements made at the weir and those made by boat for similar flow conditions are well correlated.

Discharge measurements were made at various levels of stage for Ward Lake. These discharge measurements and the corresponding stage are related to define a rating curve. This relation can be used to estimate discharge from the recorded stage data. Stage for Ward Lake is recorded at the Ward Lake Outfall streamflow gaging station, located approximately $50 \mathrm{ft}$ upstream of the west end of the weir.

Prior to the development and implementation of a direct-discharge measurement method by the USGS, two methods were used for estimating discharge at the Ward Lake Outfall. These methods included a flow equation using (broad-crested) weir coefficients and discharge-drainage area ratio calculations. Each method of estimating discharge has advantages and disadvantages. 


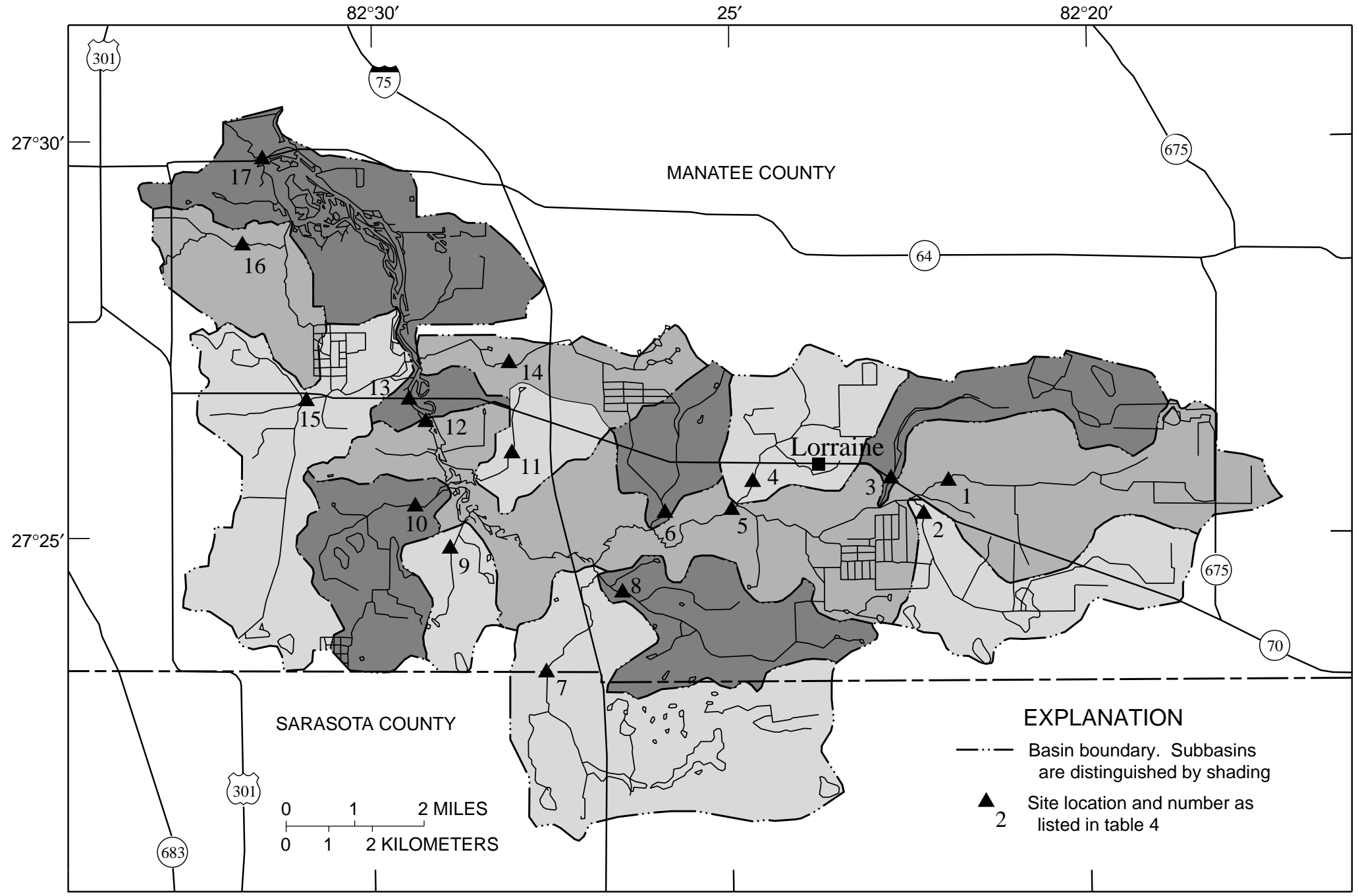

Figure 9. Location of gaging stations and subbasins in the Braden River watershed. 
Table 4. Gaging network in the Braden River watershed

\begin{tabular}{|c|c|c|c|c|c|}
\hline $\begin{array}{l}\text { Station } \\
\text { number }\end{array}$ & $\begin{array}{c}\text { USGS } \\
\text { downstream } \\
\text { order } \\
\text { number }\end{array}$ & Station name & Type of data collected & $\begin{array}{l}\text { Period } \\
\text { of } \\
\text { record }\end{array}$ & $\begin{array}{l}\text { Drainage } \\
\text { area } \\
\text { (square } \\
\text { miles) }\end{array}$ \\
\hline 1 & 02300024 & Braden River near Verna & Crest stage indicator & 1993-96 & 6.8 \\
\hline 2 & 02300025 & Tributary No. 1 to Braden River near Lorraine & Crest stage indicator & $1993-96$ & 5.2 \\
\hline 3 & 02300027 & Tributary No. 2 to Braden River near Lorraine & Crest stage indicator & $1993-96$ & 3.8 \\
\hline 4 & 02300031 & Wolf Slough near Lorraine & Crest stage indicator & $1993-96$ & 4.0 \\
\hline 5 & 02300032 & Braden River near Lorraine & Continuous discharge & $1988-96$ & 25.6 \\
\hline 6 & 02300034 & Hickory Hammock Creek near Lorraine & Continuous discharge & $1988-96$ & 2.4 \\
\hline 7 & 023000355 & Cooper Creek at University Parkway near Sarasota & Continuous discharge & $1988-96$ & 9.0 \\
\hline 8 & 02300036 & Tributary No. 1 to Cooper Creek near Lorraine & Continuous discharge & 1994-96 & 4.4 \\
\hline 9 & 02300037 & Cedar Creek near Sarasota & Continuous discharge & $1988-96$ & 1.7 \\
\hline 10 & 02300038 & Rattlesnake Slough near Sarasota & Continuous discharge & $1988-96$ & 3.8 \\
\hline 11 & 02300039 & Nonsense Creek near Bradenton & Continuous discharge & 1988-96 & 1.4 \\
\hline 12 & 02300042 & Ward Lake Outfall near Bradenton & Continuous discharge and elevation & $\begin{array}{l}1942-47 \\
1976-96\end{array}$ & 59.2 \\
\hline 13 & 02300044 & Braden River near Elwood Park & Elevation and conductance & 1989 & 60.0 \\
\hline 14 & 02300050 & Williams Creek near Bradenton & Continuous discharge & 1996 & 2.7 \\
\hline 15 & 02300056 & Gap Creek near Bradenton & Continuous discharge & 1996 & 7.2 \\
\hline 16 & 02300062 & Glen Creek near Bradenton & Continuous discharge & 1996 & 2.5 \\
\hline 17 & 02300064 & Braden River near Bradenton & Elevation and conductance & 1996 & 83.0 \\
\hline
\end{tabular}

A standard, simplified weir flow equation applied at the Ward Lake weir is:

$$
\mathrm{Q}=\mathrm{C}_{\mathrm{w}} \mathrm{L} \mathrm{H}^{3 / 2}
$$

in which $Q$ is the flow rate in cubic feet per second; $C_{w}$ is the weir coefficient; $L$ is the length of the weir, in feet, with end slope additions given by

$$
\mathrm{L}=838+24.2(\mathrm{H})
$$

and $\mathrm{H}$ is the water-level elevation over the weir, in feet. The water-level elevation over the weir, or head on the weir, is calculated by subtracting the lowest flow elevation of the weir from the water-level elevation of the gage. Weir coefficients have been explored extensively, and various coefficient tables are available for common weir shapes (Horton, 1907; and King and others, 1948). The advantage of this method is that the only data needed to calculate flow are the head of water on the weir, if the weir coefficient can be calibrated or accurately estimated. The disadvantage of this method is that using standard weir coefficients without first calibrating each individual weir may not be accurate.

The second method used to estimate flow at the Ward Lake Outfall is discharge-drainage area ratio calculations. This method estimates the flow in a basin by calculating the ratios of flow per square mile in nearby basins for which flow data are available. The advantage of this method is that flow can be estimated using only drainage area data and discharge-drainage area ratios of nearby basins. The disadvantage of this method is that comparisons made with nearby basins may not be accurate due to differing soil types, land uses, rainfall amounts, and drainage patterns. This method typically is used to calculate a monthly mean or annual mean flow rate.

Two studies also were done to define subsurface flow (seepage) around the ends of the weir and to evaluate leakage through the weir structure. A network of piezometers was installed to define seepage around the ends of the weir by measuring water-table gradients. A dye study was performed to examine potential leakage through the weir.

Ten shallow piezometers were set into the bank around both ends of the Ward Lake weir to monitor water-table fluctuations and the rate of seepage (fig. 10). The water-table gradients indicate subsurface flow around the weir. Seven piezometers were installed around the west end of the weir, an area of low topographic relief, and three around the more elevated east end. Water-level data from the three piezometers at the east end of the weir did not indicate fluctuations in the water table around the weir because of the effect from the high percentage of clay in the fill material; therefore, these data were not used. The well screen and casing of each piezometer was constructed with 2 in. PVC. The bottom of each 4.8-ft long screened interval was set at a depth of 8 to $10 \mathrm{ft}$ below 


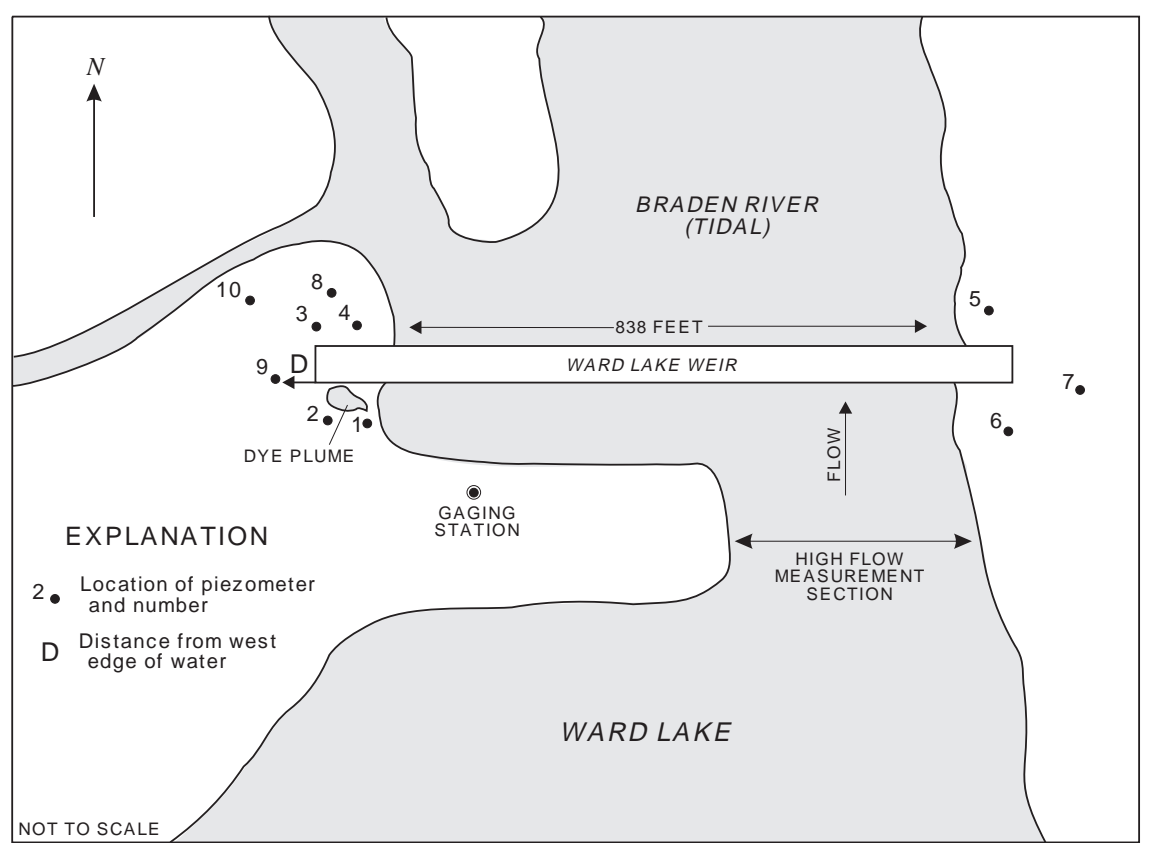

Figure 10. Areal view of Ward Lake Outfall and piezometer network. weir throughout the day, and with an automatic sampler hourly throughout the night. A sampling duration of 36 hours was determined to be long enough to detect any significant leakage through or under the weir.

\section{SURFACE DRAINAGE AND GAGE NETWORK}

The Braden River watershed drains an $83-\mathrm{mi}^{2}$ area of southcentral Manatee and northern Sarasota Counties which forms the southern part of the Manatee River Basin (fig. 1). The watershed is elongated in shape (approximately $16 \mathrm{mi}$ from east to west and ranging from about 3.5 to $9.0 \mathrm{mi}$ in width from north to south). The Braden River is approximately 22-mi long,

land surface so that the complete range of water-table fluctuations would be measured. In addition to the range of water-table fluctuations, the formation lithology at the west end of the weir also was considered in determining well configuration and depth. The lithology of the upper 5 to $6 \mathrm{ft}$ of surficial material collected during drilling at the west end of the weir was fill material deposited during construction of the weir. Most importantly, the lithology indicated a thick clay layer at approximately $10 \mathrm{ft}$ below land surface that would restrict vertical ground-water movement. The concrete sheet piles used to make the weir are imbedded into this clay layer.

To assure confidence and accuracy in established direct-discharge measurement methods, it was necessary to verify that leakage was not occurring through the sheet piles of the Ward Lake weir. To address this concern, rhodamine dye, used as a fluorescent tracer, was poured along the length of the upstream side of the weir. This was performed during a period when water from Ward Lake was not flowing over the weir, and the elevation of the lake was about $0.5 \mathrm{ft}$ below the crest of the weir. Water-level gradients between the reservoir and the tidal reach typically are over $1.5 \mathrm{ft}$, even at normal high tide. Water samples were collected along the length of the downstream side of the and has an average channel slope of $8 \mathrm{ft} / \mathrm{mi}$ for the upper $12 \mathrm{mi}$ of the river's reach (fig. 11). The lower 12 mi of river is nearly flat in the area of the reservoir and tidal reaches. The elevation of the main channel of the Braden River ranges from approximately $85 \mathrm{ft}$ above sea level at the east boundary of the watershed to sea level at the mouth of the river. The direction of flow in the Braden River generally is westward from the headwaters to approximately the midpoint of the watershed, then northwest to the mouth. The drainage pattern within the watershed generally is dendritic, formed from a series of first-order tributaries.

Natural flow characteristics of the tidally dominated lower half of the Braden River were altered in 1936 by the city of Bradenton, which constructed the Ward Lake weir to create a freshwater impoundment. The weir structure is located approximately $6 \mathrm{mi}$ upstream of the confluence with the Manatee River. The Ward Lake weir creates a permanent backwater condition to the Braden River, extending upstream for approximately 6 mi. Lower reaches of adjacent tributaries to the lake also are affected by backwater.

The Braden River can be divided into three distinct river reaches of approximate equal length: the upper, middle, and lower reaches (fig.1). This division is based on differing streamflow characteristics. 


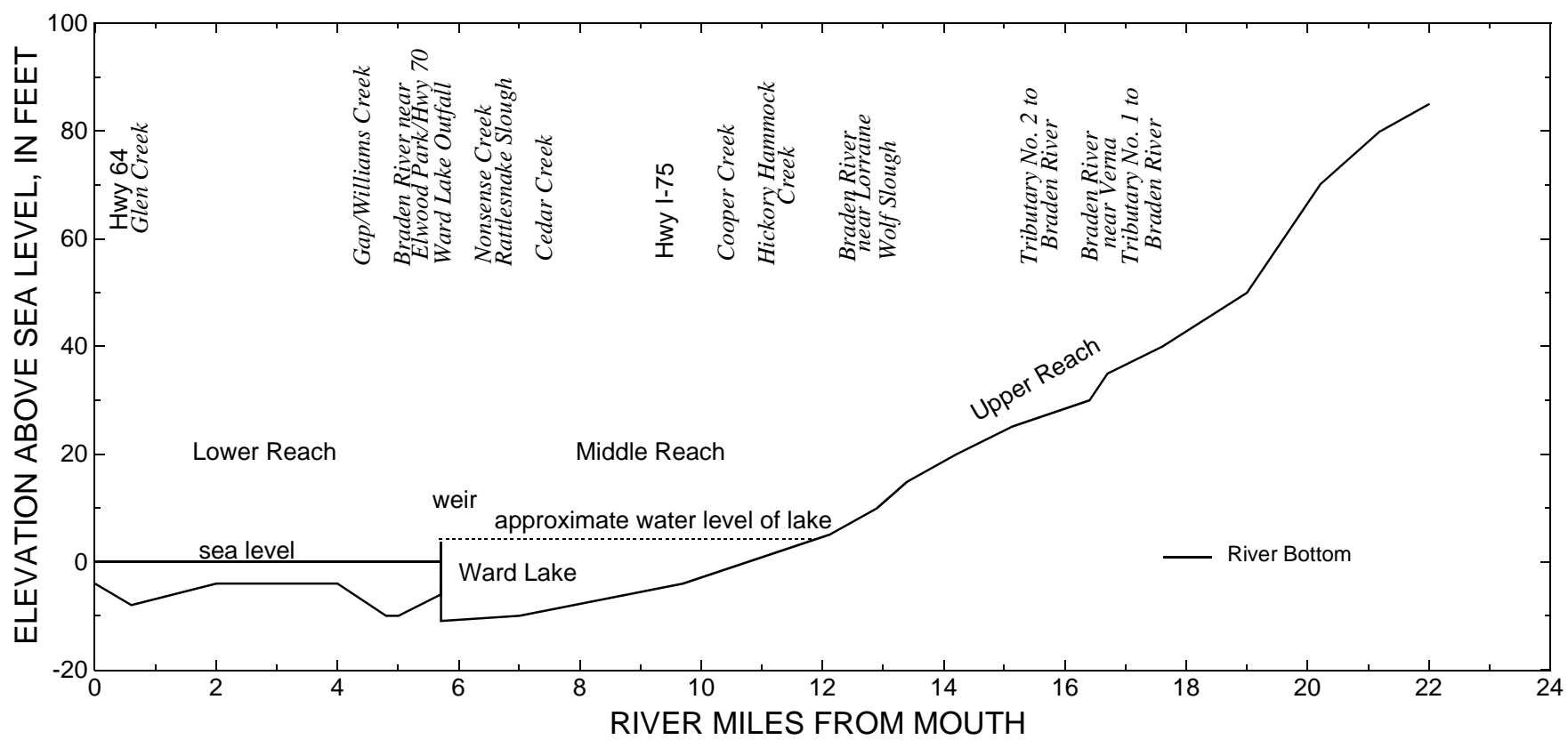

Figure 11. River-bottom profile from mouth to headwaters.

The upper reach of the Braden River is 8.6-mi long, drains a $26-\mathrm{mi}^{2}$ area of the headwaters and generally is a straight, naturally incised channel that is unaffected by backwater from Ward Lake because of the slope of the river. The middle reach of the Braden River drains a 33- $\mathrm{mi}^{2}$ section of the Braden River watershed (59 $\mathrm{mi}^{2}$ including the upper reach) and is 6.4-mi long. The meandering channel of the middle reach is characteristic of a low-gradient river and a remnant of the tidal conditions that existed prior to construction of the Ward Lake weir. Backwater conditions exist throughout the length of the middle Braden River reach and the lower reaches of all adjacent tributaries. The lower reach of the Braden River is a 6-mi long, tidally dominated channel that drains a $24-\mathrm{mi}^{2}$ area ( $83 \mathrm{mi}^{2}$ including the upper reaches), extending from its mouth at the Manatee River, upstream to the weir at Ward Lake. The lower reach of the Braden River is a typical coastal-plain estuary containing tidal flats, oyster beds, seagrass flats, salt marsh plants, and mangroves. The lower reach of the river is also a productive juvenile fishery, seasonal manatee habitat, and home to many freshwater and saltwater birds.

\section{Upper Reach}

The upper reach of the Braden River and the tributaries that flow to it typically are free of the effects of backwater from Ward Lake. These creeks flow freely through areas of minor topographic relief.

\section{Braden River near Verna}

The gaging station on the main channel of the Braden River near Verna (station 1, fig. 9), is approximately $16.5 \mathrm{mi}$ upstream of the mouth. The gage is a crest-stage indicator (CSI) partial-record station that records a peak water-level elevation during high flow events. The main channel of the river, within the gaged subbasin, is about $4.6 \mathrm{mi}$ in length and flows west from the headwaters to the gage. The subbasin is bounded on the north by Tributary No. 2 and on the south by Tributary No. 1 . The subbasin is elongated in shape (approximately 2.4-mi wide and 4.6-mi long) and drains a $6.8-\mathrm{mi}^{2}$ area of land developed primarily for agriculture and rangeland. Total topographical relief in the subbasin is about $60 \mathrm{ft}$, ranging from approximately $100 \mathrm{ft}$ above sea level (the highest area of the Braden River watershed) at the eastern boundary, to about $40 \mathrm{ft}$ above sea level at the gage. The average channel slope is about $9 \mathrm{ft} / \mathrm{mi}$.

\section{Tributary No. 1 to Braden River near Lorraine}

The Tributary No. 1 subbasin of the Braden River (station 2, fig. 9) drains approximately $5.2 \mathrm{mi}^{2}$ of primarily agricultural land at the gage and is elongated in shape (1.9-mi wide and 4.2-mi long). The tributary generally flows west for approximately $5.4 \mathrm{mi}$ from its headwaters to the station, a CSI located approximately $0.3 \mathrm{mi}$ upstream from its mouth. Total topographic 
relief in the subbasin is about $50 \mathrm{ft}$, and the average channel slope is about $10 \mathrm{ft} / \mathrm{mi}$. Extensive ditching and channelization were done within the subbasin to promote drainage of agricultural areas.

\section{Tributary No. 2 to Braden River near Lorraine}

Tributary No. 2 to Braden River is about 5.6-mi long and meanders through many low marsh areas (station 3, fig. 9). The tributary flows west for most of its length, then travels about $1.0 \mathrm{mi}$ southwest to the gage located 0.5 mi upstream from its mouth at the Braden River. The drainage area of the tributary upstream of the CSI gage is $3.8 \mathrm{mi}^{2}$. The subbasin is irregularly shaped (approximately 1.3-mi wide and $4.7 \mathrm{mi}$ long) with a total topographic relief of $43 \mathrm{ft}$ (from $79 \mathrm{ft}$ at the headwaters to $36 \mathrm{ft}$ at the mouth). The average channel slope is $7.8 \mathrm{ft} / \mathrm{mi}$. Channel modifications were made to enhance drainage of agricultural areas. Land use is mainly agriculture and rangeland.

\section{Wolf Slough near Lorraine}

Wolf Slough meanders southwest for about $2 \mathrm{mi}$ from its headwaters to the gage, a CSI (station 4, fig. 9). The station was established about $0.5 \mathrm{mi}$ upstream from the mouth of Wolf Slough where it drains an area of $4.0 \mathrm{mi}^{2}$. Wolf Slough flows through low marsh, agriculture (row crops and groves), rangeland, and residential areas, including the town of Lorraine. Several large borrow pits (now lakes) have altered parts of the drainage subbasin. The area is currently being developed for medium to high density single-family housing. The subbasin is rectangular (1.9-mi wide and 2.1-mi long) with a total relief of $45 \mathrm{ft}$. The average channel slope is about $7.9 \mathrm{ft} / \mathrm{mi}$.

\section{Braden River near Lorraine}

The upper one-third of the Braden River watershed drains to the Braden River near Lorraine streamflow-gaging station (station 5, fig. 9). The gage is instrumented by a continuous-stage recorder with water-level data transmitted by satellite. The gaging station was established upstream from the influence of backwater from Ward Lake, approximately $7 \mathrm{mi}$ upstream of the weir. The channel near the gage is deeply incised and cuts into the Caloosahatchee Formation of the surficial aquifer. The drainage area of the river upstream of the gaging station is $25.6 \mathrm{mi}^{2}$.
The Braden River flows west approximately $8 \mathrm{mi}$ from its headwaters to the Lorraine station. Land use in the subbasin is predominantly agricultural with increasing residential development. Total relief in the subbasin is approximately $90 \mathrm{ft}$ with the highest area being a knoll on the eastern drainage divide that is about $100 \mathrm{ft}$ above sea level. The elevation of the channel at the gage is approximately $10 \mathrm{ft}$ above sea level. The average channel slope is about $12 \mathrm{ft} / \mathrm{mi}$.

\section{Middle Reach}

The middle reach of the Braden River and the tributaries that flow to it typically are affected by backwater caused by the Ward Lake reservoir and weir. Gaging stations on tributaries typically are located far enough upstream from the confluence with the Braden River so that they are not affected by backwater conditions.

\section{Hickory Hammock Creek near Lorraine}

The Hickory Hammock Creek subbasin is located in the north-central region of the Braden River watershed. The tributary is 2.8-mi long and drains residential and agricultural areas. Drainage of the Hickory Hammock Creek subbasin has been altered by agricultural drainage ditches and retention ponds built to contain runoff from medium to high-density residential areas. Currently, large areas of this subbasin are being developed. The streamflow gaging station (station 6, fig. 9) is instrumented with a continuous-stage recorder at the upstream side of two $10-\mathrm{ft}$ box culverts, approximately $1,500 \mathrm{ft}$ upstream from the mouth of the creek at the Braden River. The mouth of Hickory Hammock Creek is about 5.7 mi upstream of the Ward Lake weir. The drainage area of Hickory Hammock Creek at the gaging station is about $2.4 \mathrm{mi}^{2}$. Permanent backwater conditions from Ward Lake affect the water levels in the mouth and lower reach of Hickory Hammock Creek. During periods of extreme high water, streamflow at the gaging station also can be affected by backwater. The subbasin is trapezoidal (approximately 2-mi wide and 2-mi long) and has a total relief of about $40 \mathrm{ft}$. The highest area in the subbasin is a grove along the northeastern drainage divide that is approximately $47 \mathrm{ft}$ above sea level. The elevation of the channel at the gaging station is about $7 \mathrm{ft}$ above sea level, and the average channel slope is about $14.3 \mathrm{ft} / \mathrm{mi}$. 


\section{Cooper Creek at University Parkway near Sarasota}

The Cooper Creek subbasin is located in southwest Manatee and northeast Sarasota Counties. This subbasin drains parts of Sarasota County, along the south-central part of the Braden River watershed. The creek drains improved pasture, a mine-spoil tailings area, and a residential development. The streamflow gaging station, which is instrumented with a continuous-stage recorder, was established at the ManateeSarasota County line, approximately 2 mi upstream from the mouth of Cooper Creek, which is about 4.6 mi upstream of the Ward Lake weir (station 7, fig. 9). Part of the lower reach of Cooper Creek, beginning at the mouth, is affected by backwater from Ward Lake. The drainage area of Cooper Creek at the gaging station is $9.0 \mathrm{mi}^{2}$.

The Cooper Creek subbasin is rectangular (approximately 2-mi wide and 5-mi long). The channel is approximately $5 \mathrm{mi}$ in length and has undergone extensive mining and agricultural modifications. Surface mining for topsoil, sand, and aggregates has altered the main channel and the natural drainage pattern along a 2-mi ${ }^{2}$ strip near the south-central subbasin boundary. Agricultural practices in the eastern section of the subbasin have ditched pastureland to improve surface drainage. The subbasin is poorly drained and characterized by numerous depressional ponds. Total relief in the subbasin is $37 \mathrm{ft}$, and the highest area is a roadway along the northeastern drainage divide that is $51 \mathrm{ft}$ above sea level. The elevation of the channel bed at the gaging station is about $14 \mathrm{ft}$ above sea level. Cooper Creek's channel has an average slope of $7.4 \mathrm{ft} / \mathrm{mi}$.

\section{Tributary No. 1 to Cooper Creek near Lorraine}

The Tributary No. 1 to Cooper Creek (station 8, fig. 9) streamflow gaging station was initially established as a partial-record station, but was replaced by a continuous-record gage to monitor instantaneous streamflow data. The continuous record will provide baseline data of the stream characteristics prior to, during, and after development as the subbasin land use changes from undeveloped land to a residential community. The drainage area for Tributary No. 1, a second-order tributary, is approximately $4.4 \mathrm{mi}^{2}$, and flow is to the west into Cooper Creek, about $0.5 \mathrm{mi}$ upstream of the mouth of Cooper Creek. The subbasin is irregular in shape (1.9-mi wide and 4.1-mi long), and Tributary No. 1 is about $1.5-\mathrm{mi}$ long. Total relief of the gaged subbasin is approximately $43.5 \mathrm{ft}$, with the highest elevation along the east end of the subbasin, approximately $51 \mathrm{ft}$ above sea level. The lowest elevation, approximately $7.5 \mathrm{ft}$ above sea level, is the streambed at the gaging station. Land use within the subbasin includes areas that have been mined, a golf course, and residential developments. The average channel slope is $11.6 \mathrm{ft} / \mathrm{mi}$.

\section{Cedar Creek near Sarasota}

Cedar Creek is located approximately $2 \mathrm{mi}$ upstream of the Ward Lake weir, draining part of the south-central region of the Braden River watershed. The continuous-record gaging station was established 0.4 mi upstream of the mouth (station 9, fig. 9), which is permanently affected by backwater from Ward Lake. Cedar Creek drains a highly developed subbasin that has predominantly single and multifamily homes and a golf course. The drainage area of Cedar Creek at the gaging station is about $1.7 \mathrm{mi}^{2}$. The subbasin is irregular (0.95-mi wide and 1.8-mi long). The main channel is 1.6-mi long and has been modified to increase drainage. Sections of the creek have been routed through various retention ponds for flood control. The subbasin is relatively flat and has a total relief of about $25 \mathrm{ft}$. The highest elevation is approximately $30 \mathrm{ft}$ above sea level along the eastern drainage divide. The average channel slope is $15.6 \mathrm{ft} / \mathrm{mi}$.

\section{Rattlesnake Slough near Sarasota}

The gaging station on Rattlesnake Slough is located approximately $1.2 \mathrm{mi}$ upstream of the Ward Lake weir, and drains a part of the southwestern Braden River watershed (station 10, fig. 9). The continuous-record station was established in a reach that has a natural control, approximately $0.5 \mathrm{mi}$ upstream from the mouth of the slough to avoid the effects of backwater from Ward Lake. The main channel of Rattlesnake Slough is approximately 2.5 -mi long upstream of the gage, and drains an area of $3.8 \mathrm{mi}^{2}$. The shape of the subbasin is irregular, and the drainage pattern is dendritic. Land use within the subbasin is dominated by improved pasture, a residential area, and a golf course. Total relief in the subbasin is approximately $29 \mathrm{ft}$. The highest elevation is a highway along the southwestern drainage divide that is about $35 \mathrm{ft}$ above sea level. The elevation of the channel at the gage is approximately $6 \mathrm{ft}$ above sea level. Average channel slope is approximately $5.6 \mathrm{ft} / \mathrm{mi}$. 


\section{Nonsense Creek near Bradenton}

The mouth of Nonsense Creek is located $1.1 \mathrm{mi}$ upstream of the Ward Lake weir. The creek at the gage drains a 1.4- $\mathrm{mi}^{2}$ area in the north-central area of the Braden River watershed. Until recently, the subbasin was largely undeveloped, except for a segment at the intersection of Interstate Highway 75 and State Highway 70 . Currently, the subbasin is being developed with commercial centers and medium- to high-density housing. A continuous-record streamflow-gaging station was established on Nonsense Creek approximately 0.8 mi upstream of its mouth (station 11, fig. 9). Backwater from Ward Lake does not affect flow at the gage because of the control and elevation of the gage. The subbasin is rectangular (approximately 0.9 -mi wide and 1.6-mi long). The main channel is about 0.9-mi long and flows from a small lake surrounded by marsh at the headwaters. The subbasin generally is flat and has a total relief of approximately $20 \mathrm{ft}$. The highest elevation in the subbasin is about $43 \mathrm{ft}$ above sea level along the northeastern drainage divide. The lowest elevation is the stream channel at the gaging station, $13 \mathrm{ft}$ above sea level. The average channel slope is $33 \mathrm{ft} / \mathrm{mi}$.

\section{Ward Lake Outfall near Bradenton}

The Ward Lake Outfall (originally the John Ward Dam) is an 838-ft-long sheet-pile weir that impounds the Braden River to form Ward Lake (also known locally as the Bill Evers Reservoir), approximately $6 \mathrm{mi}$ upstream from the mouth. The weir separates the upper freshwater part of the Braden River from the tidally influenced, brackish-water estuary downstream.

Originally built in 1936 , the 838 -ft-wide weir was reconstructed in 1985 with $20-\mathrm{ft}$ sections of 12 -in. thick concrete sheet pile, driven to a depth of about $20 \mathrm{ft}$ below sea level, except at the edges where $40 \mathrm{ft}$ of 8-in. thick sheet pile was driven $12 \mathrm{ft}$ below sea level (written commun., Smith and Gillespie Engineering, 1982). The sheet pile was finished with a 2.3-ft-wide cap. In addition, continuous synthetic membrane liners were bolted at the top of the sheet pile at both the upstream and the downstream faces of the weir and covered with rip-rap. The upstream crest of the weir averages 3.93 feet above sea level, but varies between 3.82 and $4.10 \mathrm{ft}$ above sea level (fig. 12, Smith and Gillespie Engineering, 1990). Due to the effects of changing influences such as wind generated waves, seiche, algae growth, and hydrilla on the water

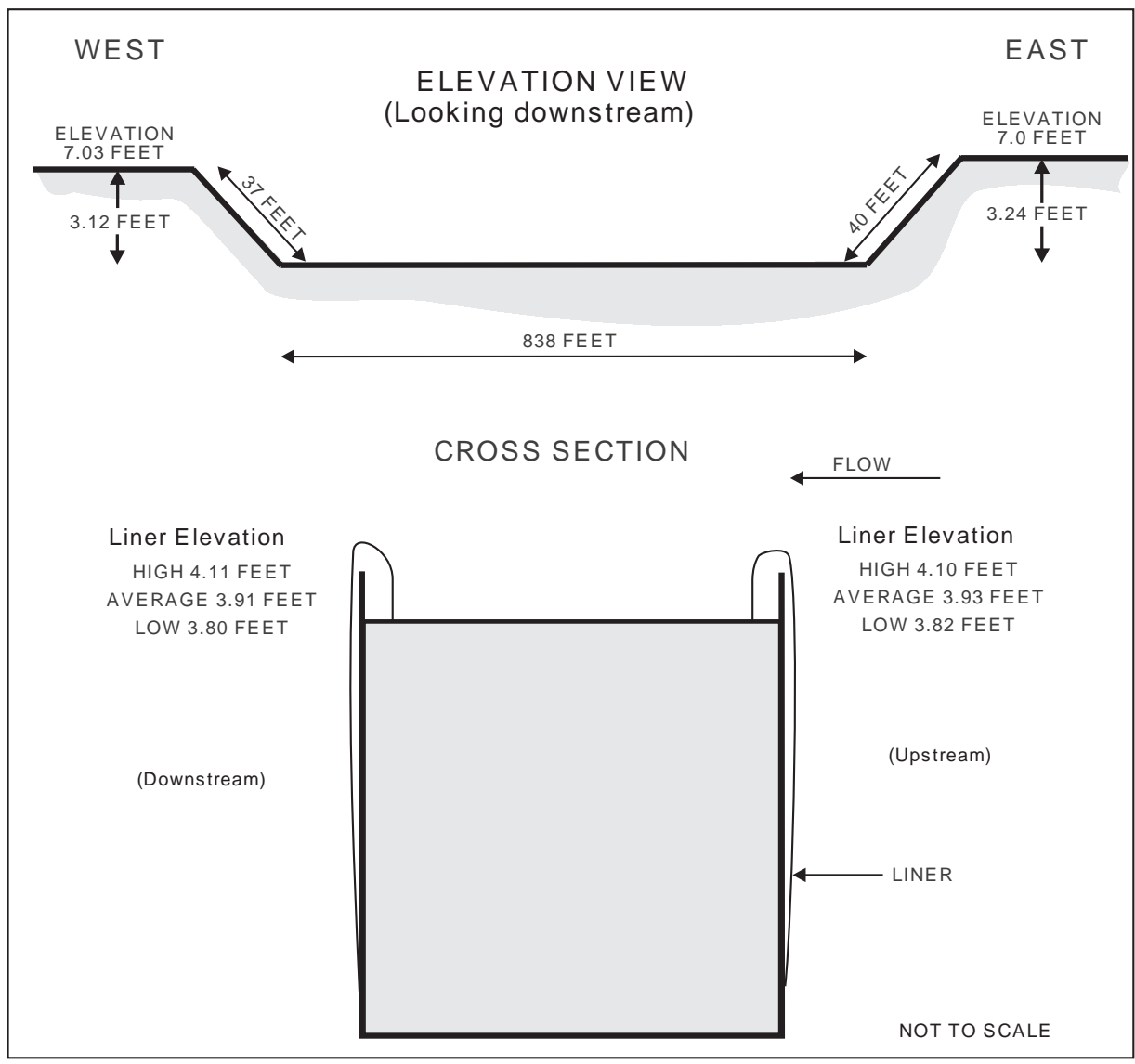

Figure 12. Ward Lake weir survey. (Modified from Smith and Gillespie, 1990.) 
levels and flow at the weir, it is very difficult to determine the exact water elevation of zero flow. Although the survey (fig. 12) indicted the lowest elevation of the upstream crest of the weir to be $3.82 \mathrm{ft}$, field reconnaissance has shown the elevation of zero flow to be, at times, $3.80 \mathrm{ft}$. The water surface of the downstream reach, even at high tide, is usually more than $1.5 \mathrm{ft}$ below the top of the weir. Water-level fluctuations for the tidal reach of the Braden River can be affected by storm surge and seiche created by tropical storms and hurricanes. On March 13, 1993, the gage at the Elwood Park station (station 13, fig. 9) recorded a water-level elevation of $4.91 \mathrm{ft}$ above sea level due to an unnamed tropical storm. During this elevated tide, brackish water from the estuary contaminated the drinking-water supply for the city of Bradenton, causing the water-treatment plant to shut down for several hours. Fluctuations of stage in Ward Lake have ranged from $2.60 \mathrm{ft}$ below sea level to $6.15 \mathrm{ft}$ above sea level.

The drainage area of the Braden River watershed at the Ward Lake Outfall gaging station is $59.2 \mathrm{mi}^{2}$ (station 12, fig. 9). Effects of backwater from the lake extend upstream approximately $6 \mathrm{mi}$ to just downstream of the gaging station at Braden River near Lorraine. Total relief in the subbasin is about $43 \mathrm{ft}$ with the highest elevation in the subbasin about $47 \mathrm{ft}$ above sea level at the northeastern drainage divide. The average channel slope is approximately $6.1 \mathrm{ft} / \mathrm{mi}$.

\section{Lower Reach}

The lower 6-mi reach of the Braden River and the tributaries that flow to it typically are affected by the tidal fluctuations in the estuary. The gaging stations on the tributaries to this lower reach are located upstream from their mouth far enough so that tidal effects are not present.

\section{Braden River near Elwood Park}

The Braden River gaging station near Elwood Park (station 13, fig. 9) was established about 2,100 ft downstream of the Ward Lake weir in the tidal estuary part of the Braden River. Tidal elevations and conductance are recorded. Conductance (which is related to salinity) is recorded at this station to monitor freshwater flows from Ward Lake into the receiving tidal estuary and also to measure the movement of brackish water (the saline wedge) from the estuary toward the weir. Two conductivity probes were attached to a pile on the Highway 70 bridge, one probe near the top of the water column and the other near the streambed, so that salinity stratifications could be measured. These stratifications are somewhat artificial in that the depth at the bridge (about $12 \mathrm{ft}$ ) is greater than the average stream depth (about 3-6 ft). The consequence of this deeper than average stream depth is that the brackish water pools around the bridge.

\section{Williams Creek near Bradenton}

Williams Creek is located about 4.8 mi upstream of the mouth of the Braden River, and drains a 2.7- $\mathrm{mi}^{2}$ area at the streamflow-gaging station (station 14, fig. 9). Williams Creek flows west from its headwaters, formed from several interconnected depressions, for approximately $4.1 \mathrm{mi}$ where it empties into the lower reach of the Braden River. The gage record is not affected by the tidal waters of the Braden River. The subbasin, roughly 4-mi long and 1-mi wide, is bisected by Interstate Highway 75 . Topography in the eastern two-thirds of the subbasin is flat and poorly drained, with an elevation ranging from about 25 to $45 \mathrm{ft}$ above sea level. The slope of the gaged Williams Creek channel is about $8.8 \mathrm{ft} / \mathrm{mi}$. Parts of the upper subbasin have been ditched to improve drainage for agriculture and residential development. Topographic relief in the western one-third of the subbasin is more pronounced and the channel slope is about $14.7 \mathrm{ft} / \mathrm{mi}$.

\section{Gap Creek near Bradenton}

Gap Creek empties into the lower reach of the Braden River about 4.8 mi upstream of the mouth of the Braden River, on the opposite bank and just upstream of Williams Creek. Gap Creek drains $7.2 \mathrm{mi}^{2}$ at the streamflow-gaging station (station 15, fig. 9), located approximately $1.8 \mathrm{mi}$ upstream of the creek's mouth. Gap Creek is formed at the confluence of two tributaries and the Pearce Canal. Flowing from south to north, the 3.5-mi-long Pearce Canal drains the largest part of the subbasin. The drainage divide for the Pearce Canal is difficult to determine because the canal also drains south into another drainage subbasin outside of the Braden River watershed. An earlier study indicates that the canal starts to flow north about 1 mi north of the county line (Tampa Bay Regional Planning Council, 1986). Land use within the subbasin is largely dominated by residential, commercial, and industrial developments, interspersed among numerous citrus groves. Runoff from Highway 301, which 
forms part of the western watershed boundary, flows into Gap Creek. Because of the Pearce Canal and the heavily developed areas, the subbasin boundaries are difficult to delineate. The subbasin is irregular, roughly 4.8-mi long, and almost 3-mi wide. Land-surface elevations range from about $35 \mathrm{ft}$ above sea level near the northern and southern extremes of the subbasin to sea level at the mouth of the creek.

The channel slope of Gap Creek is indeterminate from topographic maps because the creek has been deeply channelized for most of its length. Channelization allows tidal influences, including backwater, to extend upstream from the mouth of Gap Creek at the Braden River, to an undetermined distance upstream.

\section{Glen Creek near Bradenton}

Glen Creek (station 16, fig. 9), the largest tributary to the tidally affected Sugarhouse Creek, is the farthest downstream station monitored for discharge in the Braden River watershed. The drainage area contribution from Glen Creek accounts for about one-half of the total drainage area within the Sugarhouse Creek subbasin. The drainage area of Glen Creek is $2.5 \mathrm{mi}^{2}$ at the streamflow gaging station, which is approximately $0.75 \mathrm{mi}$ upstream from the mouth of the creek. The Glen Creek subbasin is oblong (about 2.0-mi long and 1.0-mi wide) and drains an urban area, a large orange grove, and a citrus processing plant. The whole length of Glen Creek has been channelized to contain runoff from large storm events. Dredging of the lower reach of Glen Creek has resulted in the exposure of a limestone channel, which at one location creates an abrupt drop (waterfall) of approximately $2 \mathrm{ft}$. The drop helps isolate the gaging station from potential effects of tide and backwater from the Braden River. The headwaters to Glen Creek originate in an urban environment at a heavily industrialized area which is comprised of impervious surfaces. Discharge pipes route drainage from U.S. Highway 301 to Glen Creek. The elevation in the Glen Creek subbasin ranges from approximately $30 \mathrm{ft}$ above sea level along the southwestern boundary divide to sea level at the mouth. The slope of the 2-milong main channel, from the headwaters to the mouth, is about $15 \mathrm{ft} / \mathrm{mi}$.

\section{Braden River near Bradenton}

The Braden River near Bradenton gage is at the mouth of the Braden River just upstream of the confluence with the Manatee River (station 17, fig. 9). As the
Braden River approaches the Manatee River, it begins to widen and flatten into a coastal plain estuary. The gage is located on a public boat dock on the left bank, about $50 \mathrm{ft}$ upstream of the State Road 64 bridge.

Because of the shallow depths (less than $2 \mathrm{ft}$ ), only one conductance probe was needed. Tidal elevation and conductance are measured at 15 minute intervals.

\section{Streamflow at the Ward Lake Outfall}

The Ward Lake weir has been in place for almost 60 years, separating the tidal Braden River estuary from the freshwater reservoir. A preliminary study was undertaken in 1992 to directly measure streamflow at the Ward Lake weir. Previously, streamflow at the Ward Lake weir had been estimated using weir coefficient equations and discharge-drainage area ratio calculations. Results of these two methods of estimating streamflow are compared to results of the direct discharge measurement methods. A study was done to determine the extent of seepage around the ends of the weir and another study investigated potential leakage through the weir.

\section{Direct Streamflow Measurements}

Measurements of discharge at the Ward Lake weir were made at various water-level stages. These discharge measurements and corresponding stages were used to define a relation between stage and discharge (a rating curve) for the Ward Lake weir (fig. 13). The rating was developed from a series of discharge measurement methods that included volumetric, pygmy and AA-standard current-meter, by wading rod and boat. For a complete description of USGS discharge measurement techniques see Rantz and others, 1982. The rating curve shown in figure 13 was put into use on October 1, 1993, and used for the 1994 and 1995 water years. Ratings are updated and modified as more data are collected. Discharge for the Ward Lake Outflow ranges from 0 to $7,350 \mathrm{ft}^{3} / \mathrm{s}$.

Annual mean discharge at the Ward Lake Outfall for water years 1993 and 1994 was 59.7 and $57.3 \mathrm{ft}^{3} / \mathrm{s}$, respectively (Coffin and Fletcher, 1993; 1994).

Because of long periods of no flow and short periods of very high flow at the Ward Lake weir, daily mean flows are not reflected in annual mean discharge data. In the study area, as in many parts of west-central Florida, annual mean flows are strongly affected by the high flow events of the wet season (Hammett, 1992). To better understand the flow conditions at the 


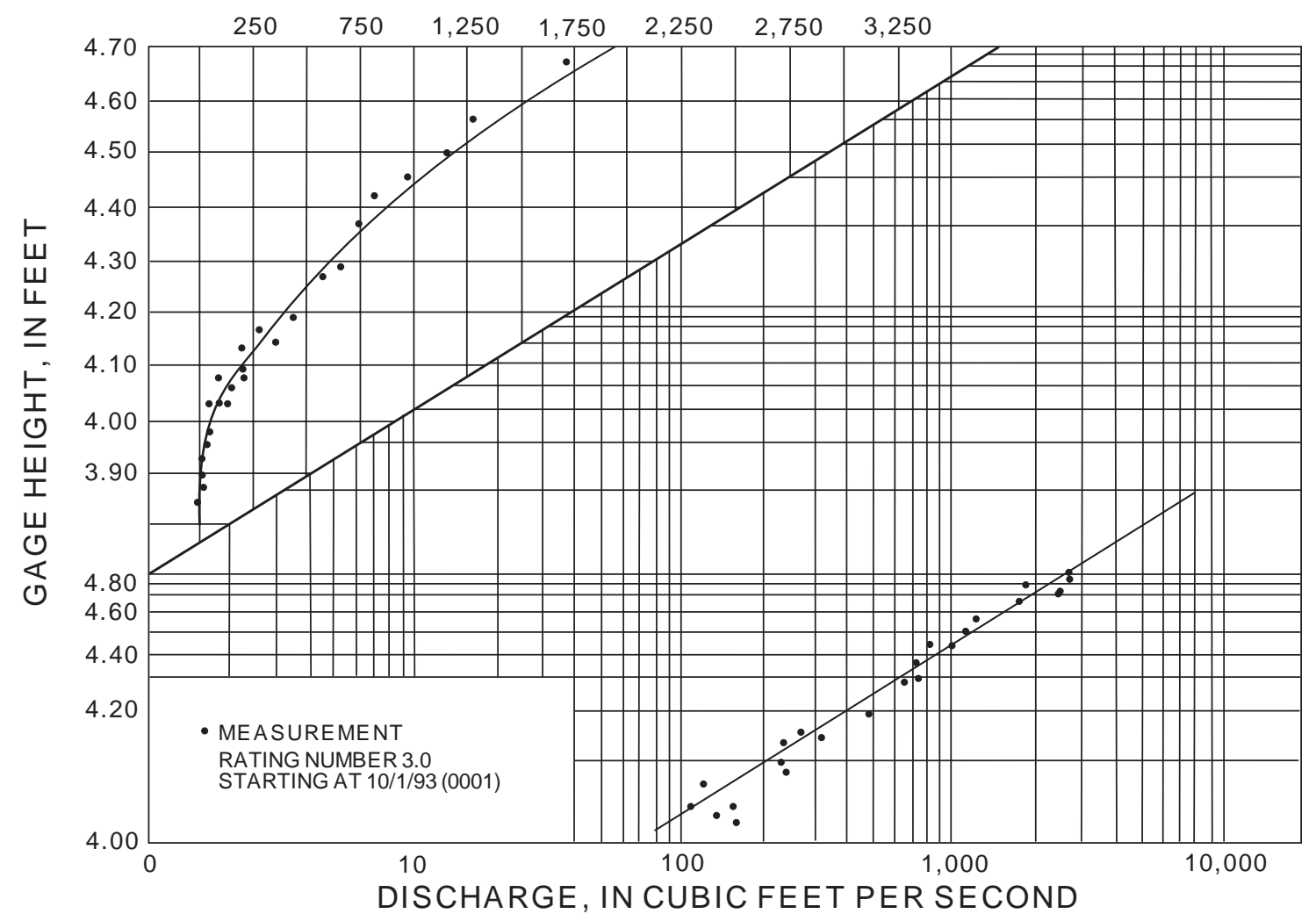

Figure 13. Rating curve for Ward Lake Outfall near Bradenton.

Ward Lake weir, the flow duration curve, or exceedence curve, for water years 1993 and 1994 is shown in figure 14 . Figure 14 shows the duration, as a percentage of time, for which a daily mean discharge was equaled or exceeded. Note that the daily mean discharge exceeded $0.01 \mathrm{ft}^{3} / \mathrm{s}$ about 70 percent of the time, $4.1 \mathrm{ft}^{3} / \mathrm{s} 50$ percent of the time, $200 \mathrm{ft}^{3} / \mathrm{s} 10$ percent of the time, and $330 \mathrm{ft}^{3} / \mathrm{s} 5$ percent of the time. The annual mean discharge of about $60 \mathrm{ft}^{3} / \mathrm{s}$ is equaled or exceeded less than 25 percent of the time. Thus, there is a large skew in the annual mean and daily mean discharge data.

\section{Streamflow Estimate Calculations}

A standard engineering practice for determining discharge over a weir includes using weir coefficient equations. These equations use the stage data for depth of water over the weir (head) and the physical characteristics of the weir, including type and length, to calculate discharge. The Ward Lake weir is classified as a broad-crested weir. For a discharge of $59 \mathrm{ft}^{3} / \mathrm{s}$, the corresponding gage height from rating No. 3 is $3.99 \mathrm{ft}$.
For this stage, $3.99 \mathrm{ft}$ minus the $3.80 \mathrm{ft}$ zero flow gage height gives a head of $0.19 \mathrm{ft}$. For a head of $0.19 \mathrm{ft}$, King and others (1948) suggest a weir coefficient for a broad crested weir of 2.70. The length of the weir, including end slopes, is calculated using equation 2 as:

$$
\mathrm{L}=838 \mathrm{ft}+24.2(0.19 \mathrm{ft})=843 \mathrm{ft}
$$

and calculating discharge with equation 1 :

$$
\mathrm{Q}=\mathrm{C}_{\mathrm{w}} \mathrm{LH}^{3 / 2}=(2.70)(843)(0.19)^{3 / 2}=188 \mathrm{ft}^{3} / \mathrm{s} \text {. }
$$

This example shows the limitation of using the standard flow equation, for one gage height and corresponding discharge, without having calibrated the weir. In this example, a stage of $3.80 \mathrm{ft}$ was used for the zero flow elevation. However, if no field reconnaissance had been done, it would be reasonable to assume that the lowest elevation $(3.82 \mathrm{ft})$ of the upstream crest is the elevation at which flow would begin. Following the same example as above with a stage of $3.99 \mathrm{ft}$ but an elevation of zero flow of $3.82 \mathrm{ft}$, the calculated discharge would be $159 \mathrm{ft}^{3} / \mathrm{s}$. Had a mean elevation for the upstream crest been used $(3.93 \mathrm{ft})$ for the elevation of zero flow, the above example for a stage of $3.99 \mathrm{ft}$ 


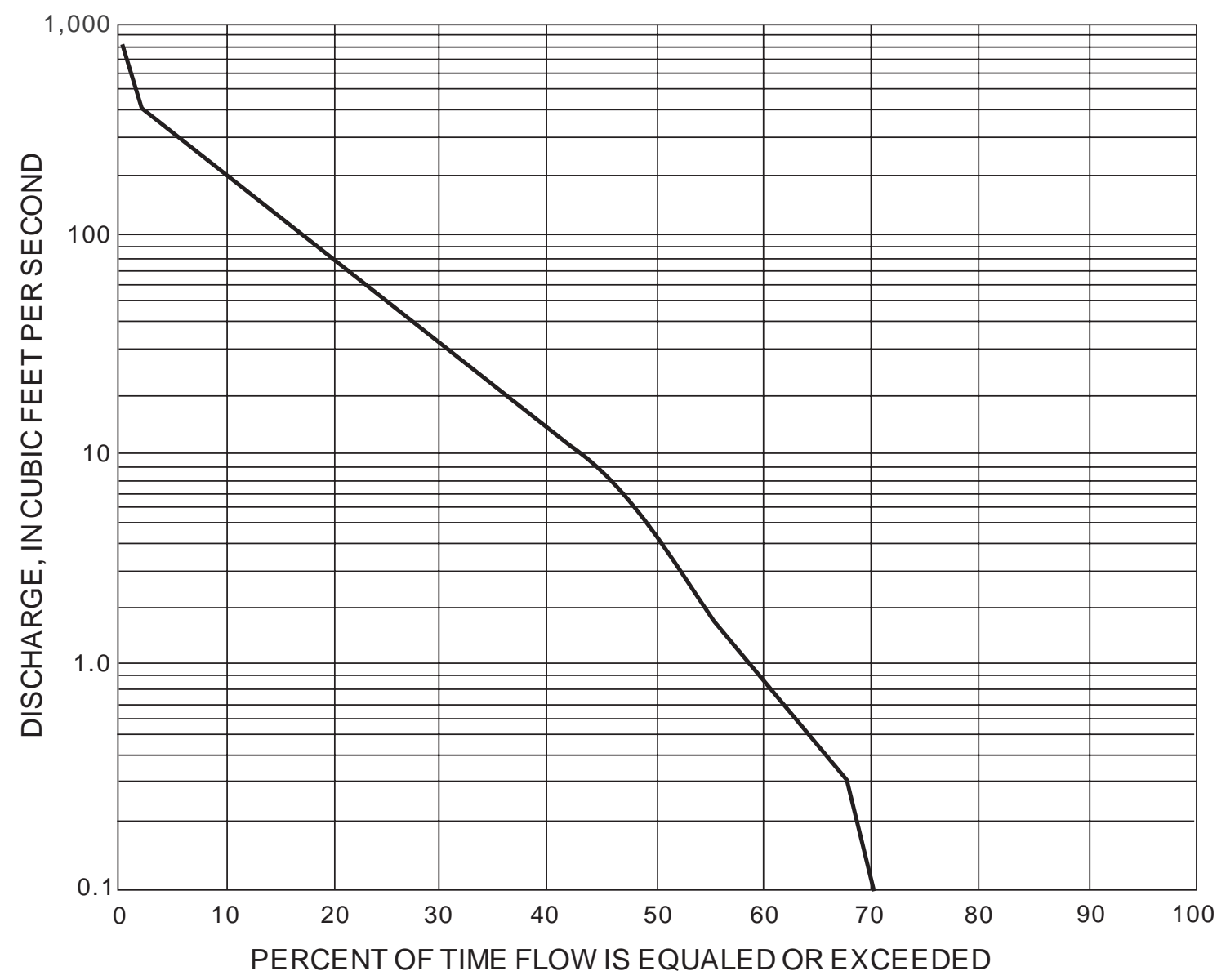

Figure 14. Flow duration curve for Ward Lake Outfall, water years 1993-94.

would result in a discharge of $33.3 \mathrm{ft}^{3} / \mathrm{s}$. The stagedischarge rating developed for the weir shows that at the mean elevation of the upstream weir crest, $3.93 \mathrm{ft}$, about $10 \mathrm{ft}^{3} / \mathrm{s}$ of flow is discharging over the weir. It is significant that this amount of discharge was exceeded less than 45 percent of the time for water years 1993 and 1994. These calculations show how sensitive the theoretical calculations of discharge using a weir coefficient equation are to the value used for the elevation of zero flow, especially for a weir 838 -ft long. The discharge equations used for this analysis (eq. 1) are best used at high flows when the weir is fully submerged, a water-level elevation of at least $4.10 \mathrm{ft}$ (fig. 13) on the Ward Lake weir. At this water level, rating 3 shows that about $212 \mathrm{ft}^{3} / \mathrm{s}$ is discharging over the weir, an amount exceeded less than 10 percent of the time.

To increase the accuracy of weir coefficient formulas for calculating discharge at the Ward Lake weir, the weir should be calibrated for each head of flow.
It is possible to examine more closely the relation between the weir coefficients and measured discharge by rearranging equation 1 as

$$
\mathrm{C}_{\mathrm{w}}=\mathrm{Q} /\left(\mathrm{LH}^{3 / 2}\right) .
$$

Weir coefficients, calculated from equation 5 and plotted with the corresponding gage heights, are shown in figure 15 as well as coefficients calculated by using measured and rating discharges. Also shown are coefficients calculated for individual discharge measurements using the length of weir $\mathrm{L}$ as computed by equation 2 and by the length of weir that was measured discharging over the weir. At low flows (less than $200 \mathrm{ft}^{3} / \mathrm{s}$ ), because of the undulating shape of the weir crest, the length of flow over the weir can be much less than the $838 \mathrm{ft}$ minimum in equation 2 . For example, a measurement made at a gage height of 3.90 measured a length of flow on the weir of $140 \mathrm{ft}$, but using equation 2 the calculated length would be $840 \mathrm{ft}$. 


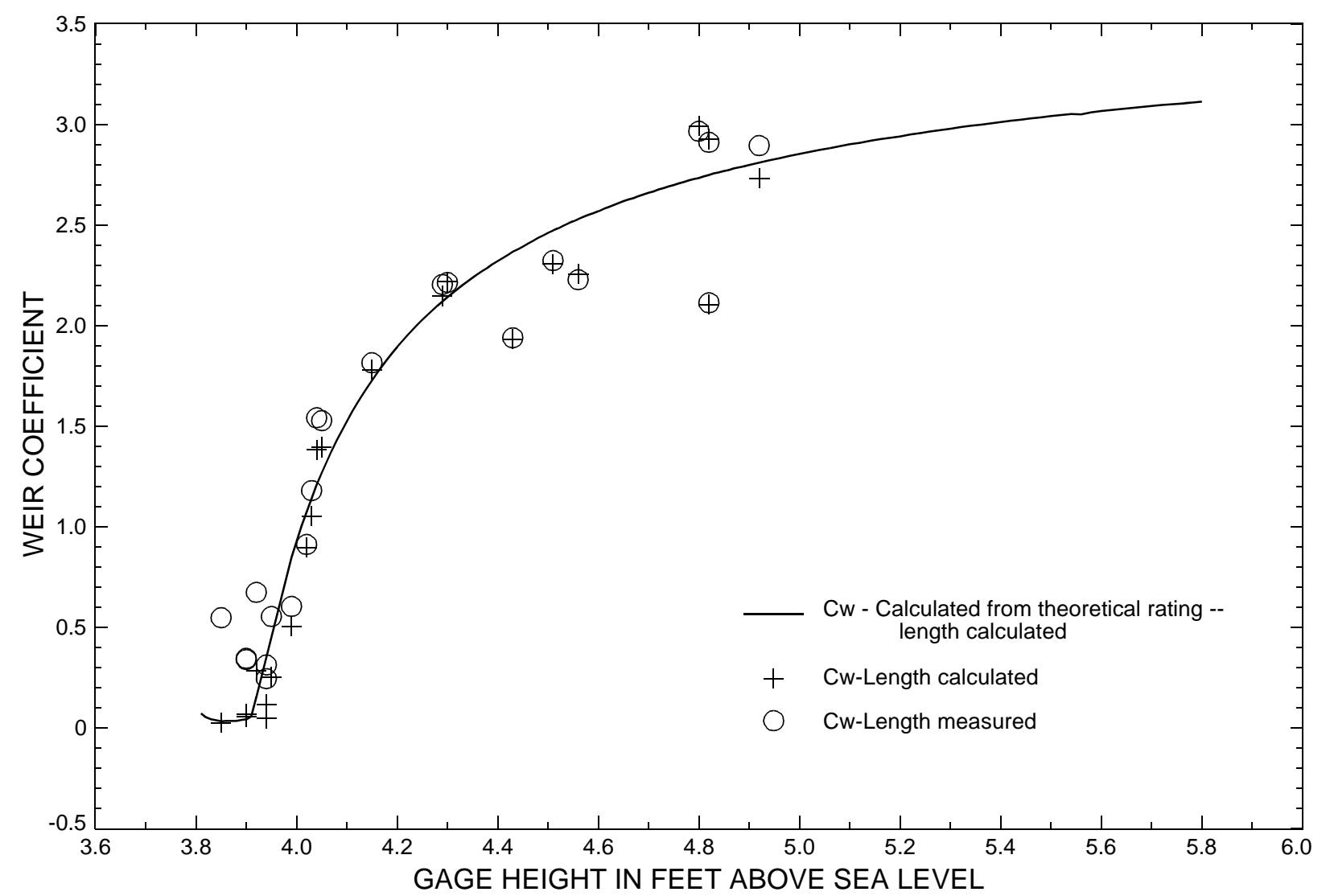

Figure 15. Gage heights and weir coefficients.

The difference in using a calculated or measured length is most apparent at gage heights of less than $4.10 \mathrm{ft}$ when the weir is not fully inundated.

The weir formula (eq. 1) uses a weir coefficient that typically is calibrated for each individual weir and changes for different ranges of water levels (head) on the weir. Calibrated Ward Lake weir coefficients for a range of head from 0 to $2.0 \mathrm{ft}$, covering the period of record range of flow, are shown in figure 15 . The coefficients change rapidly at the low gage heights, but begin to stabilize above about $4.6 \mathrm{ft}$. When weir coefficient formulas are used in the future to calculate discharge at the Ward Lake weir, figure 15 can be used to accurately choose an appropriate weir coefficient for each range of head on the weir.

The smallest weir coefficient calculated was 0.023 using the calculated length method and 0.244 using the measured length method. The largest coefficient calculated was 2.99 using the calculated length method and 2.97 using the measured length method. The smallest weir coefficient calculated from the theoretical rating developed from the measurements and gage readings was 0.032 and the largest weir coefficient calculated was 3.11. Weir coefficients calculated using rating curve number 3 used the calculated length for L (eq. 2).

Wanalista (1989) used a discharge/drainage area ratio calculation to estimate the annual streamflow at the Ward Lake weir. Wanalista estimated a ratio of $1 \mathrm{ft}^{3} / \mathrm{s}$ of annual mean flow for every $1 \mathrm{mi}^{2}$ of drainage basin using five watersheds of known area and annual mean flow, as recorded by the USGS. This 1:1 ratio of annual mean discharge to drainage area is not an exact fit for the data he presented but is what he used as an estimate. Using this 1:1 ratio and a drainage area of the Braden River above the Ward Lake weir of $60.3 \mathrm{mi}^{2}$ (Camp, Dresser, and Mckee Inc., 1985), Wanalista estimated an annual mean flow of $60.3 \mathrm{ft}^{3} / \mathrm{s}$ for the Ward Lake weir. This estimate is within 1 to 5 percent of the annual mean discharges reported by the USGS for water years 1993 and 1994, respectively. The 1:1 ratio seems to work well to estimate annual mean flow for the 1993 and 1994 water years, but may need to be adjusted to account for particularly wet or dry years. 


\section{Seepage and Leakage Studies}

Two investigations were undertaken to determine whether a significant volume of water was seeping around or through the Ward Lake weir. In the first investigation, a series of water-level monitors were installed and the water levels were measured at both ends of the weir. In the second investigation, two leakage tests were conducted using rhodamine dye as a tracer.

Shallow water-table wells (piezometers) were installed to monitor water-table fluctuations at the ends of the Ward Lake weir (fig. 10), and were measured 11 times during the period from December 1992 to September 1994 (fig. 16). The data are shown in table 5. The data show the water-table gradients declining in a clockwise direction, indicating a similar flow path for each measurement. Fluctuations in the periodically measured water-table levels at piezometer No. 1, at the upstream side of the west-end of the weir, ranged from a maximum altitude of $3.54 \mathrm{ft}$ above sea level to a minimum of $2.69 \mathrm{ft}$ above sea level. Watertable fluctuations at piezometer No. 4 , at the downstream side of the weir, were lower, ranging from a maximum altitude of $2.71 \mathrm{ft}$ above sea level to a minimum of $1.12 \mathrm{ft}$ above sea level.
To determine the rate of ground-water seepage through the riverbank around the west end of the weir, rhodamine dye was used as a fluorescent tracer in a time-of-travel study. The concrete sheet piles that form the west end of the weir extend horizontally approximately $40 \mathrm{ft}$ into the river bank. A measured volume of rhodamine dye was placed in piezometer No. 1, having the highest water-level altitude and closest proximity to Ward Lake (fig. 10). Water samples were collected daily from piezometers $2,3,4,9$, and 10, and analyzed with a fluorometer for traces of rhodamine dye. After 17 consecutive days of sampling, the dye tracer remained undetected in all of the five monitored piezometers. Because water samples from the nearest downgradient piezometer, No. 2, did not record the dye tracer, a drive-point ground-water sampler was used to locate the extent of the dye-tracer seepage plume by drilling and sampling numerous locations downgradient from the dye injected piezometer. The farthest point sampled with the drive-point sampler that indicated dye tracer downgradient of the injected piezometer was about $13 \mathrm{ft}$ from the injected piezometer. The flow path of the dye, determined from numerous drive-point water samples, migrated from piezometer No. 1 to the northwest, about $20 \mathrm{ft}$ from the

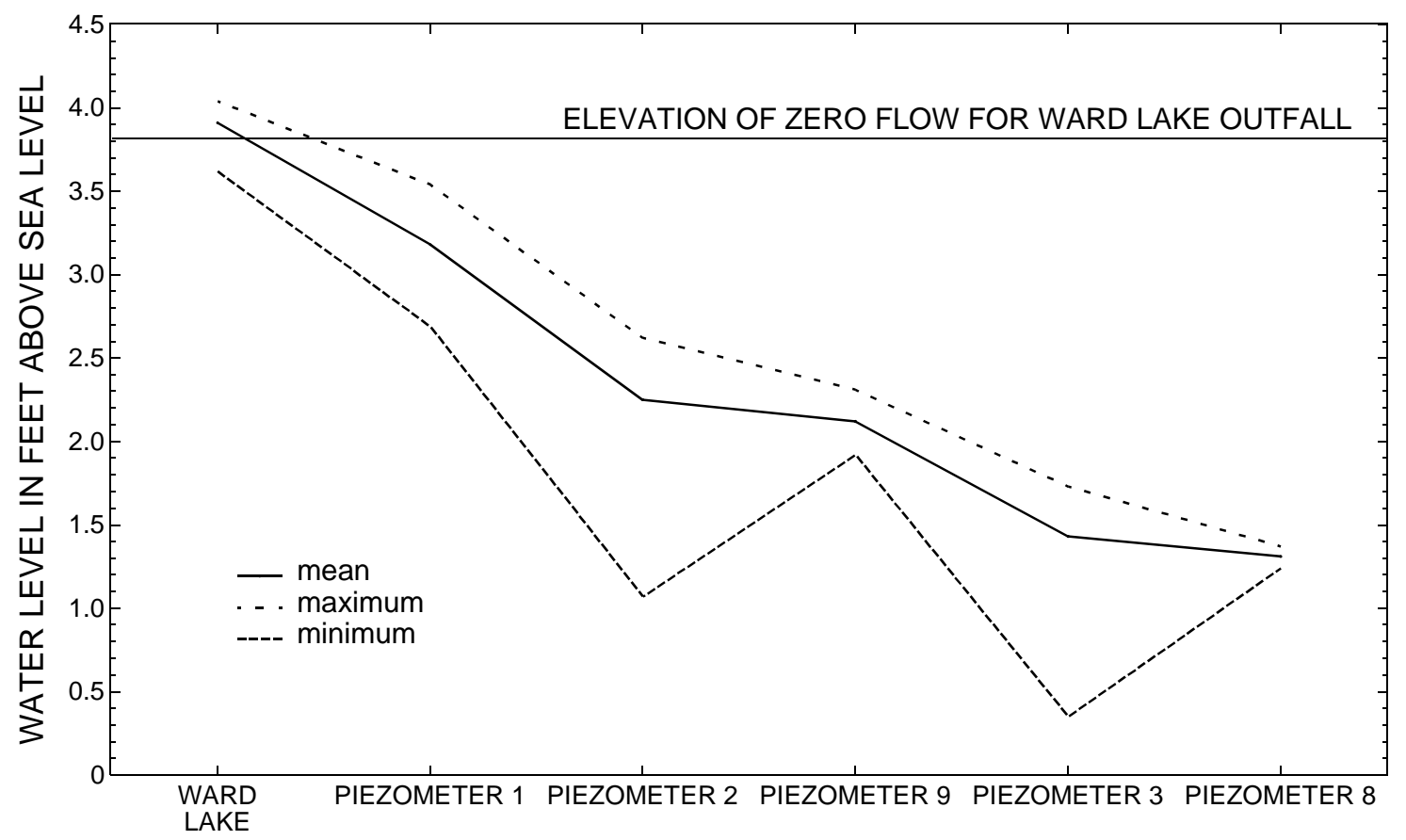

Figure 16. Mean, maximum, and minimum water levels in piezometers at Ward Lake Outfall. 
Table 5. Piezometer water levels around Ward Lake weir

[All values are in feet above sea level]

\begin{tabular}{|c|c|c|c|c|c|c|c|c|c|c|c|}
\hline 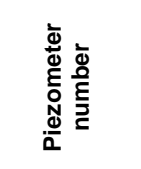 & 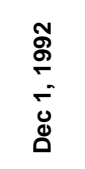 & 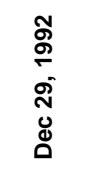 & $\begin{array}{l}\mathscr{O} \\
\stackrel{0}{\sigma} \\
\infty \\
\infty \\
\stackrel{0}{0} \\
\stackrel{0}{L}\end{array}$ & 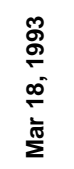 & 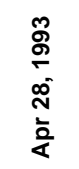 & 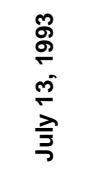 & $\begin{array}{l}\mathscr{O} \\
\stackrel{5}{\leftarrow} \\
\text { m } \\
\text { oे }\end{array}$ & 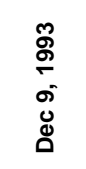 & 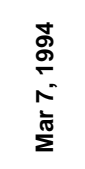 & 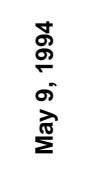 & 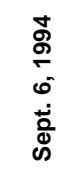 \\
\hline 1 & 3.23 & 3.29 & 3.54 & 3.47 & 3.39 & $--^{\mathrm{a}}$ & 3.12 & 2.69 & 3.08 & 2.89 & 3.15 \\
\hline 2 & 2.39 & 2.38 & 1.07 & 2.44 & $--^{\mathrm{a}}$ & $--^{a}$ & 2.62 & 2.02 & 2.46 & 2.28 & 2.58 \\
\hline 3 & 1.48 & 1.35 & 1.73 & 0.35 & 1.62 & 1.70 & 1.68 & 1.55 & $--^{b}$ & $--{ }^{b}$ & $--{ }^{b}$ \\
\hline 4 & 1.19 & 1.12 & 1.54 & 2.71 & 1.31 & 1.39 & 1.45 & 1.35 & 1.38 & 1.51 & 1.48 \\
\hline 5 & 0.79 & 0.57 & 1.42 & 0.91 & 1.27 & 1.32 & $--^{a}$ & 1.23 & 1.19 & 1.53 & 1.62 \\
\hline 6 & 3.43 & 3.56 & 3.82 & 3.80 & 3.67 & 3.70 & $--^{\mathrm{a}}$ & 3.34 & 3.70 & 3.45 & 3.81 \\
\hline 7 & 3.00 & 2.99 & 3.46 & 3.26 & 3.16 & 3.23 & $--^{\mathrm{a}}$ & 2.90 & 3.21 & 2.95 & 3.45 \\
\hline 8 & $--^{c}$ & $--^{c}$ & $--^{c}$ & $--^{c}$ & $--^{c}$ & $--^{c}$ & 1.32 & 1.26 & 1.24 & 1.37 & 1.37 \\
\hline 9 & $--^{c}$ & $--^{c}$ & $--^{c}$ & $--^{c}$ & $--^{c}$ & $--^{c}$ & 2.31 & 1.92 & 2.16 & 1.95 & 2.27 \\
\hline 10 & $-^{c}$ & $-^{c}$ & $--^{c}$ & $--^{c}$ & $--^{c}$ & $--^{c}$ & 1.22 & 1.19 & 1.15 & 1.28 & 1.22 \\
\hline Ward Lake & 3.77 & 3.85 & 3.98 & 4.04 & 3.99 & 4.03 & 4.03 & 3.62 & 3.98 & 3.75 & 3.94 \\
\hline $\begin{array}{l}\text { tidal } \\
\text { elevation }\end{array}$ & 10.7 & 10.4 & 10.2 & 9.8 & 10.4 & 10.4 & 10.4 & 10.8 & 10.3 & 10.7 & 10.3 \\
\hline $\begin{array}{l}{ }^{\mathrm{a}} \text { Missing d } \\
{ }^{\mathrm{b}} \text { Missing d }\end{array}$ & niez & eter de & yyed. & & $\begin{array}{l}{ }^{\mathrm{c}} \mathrm{M} \\
{ }^{\mathrm{d}}{ }_{\mathrm{Ti}}\end{array}$ & $\begin{array}{l}\text { g data } \\
\text { levati }\end{array}$ & $\begin{array}{l}\text { ezome } \\
\text { at Brac }\end{array}$ & $\begin{array}{l}\text { not es } \\
\text { River }\end{array}$ & $\begin{array}{l}\text { lished. } \\
\text { ar Elwo }\end{array}$ & Park. & \\
\hline
\end{tabular}

end of the west end of the weir (fig. 10). The seepage velocity around the weir was calculated as:

$$
\mathrm{V}=13 \mathrm{ft} / 17 \text { days }=0.76 \mathrm{ft} / \text { day }=8.8 \times 10^{-6} \mathrm{ft} / \mathrm{s}
$$

where $\mathrm{V}$ is the velocity of seepage around the weir. To calculate an area of seepage, the extent of flow was determined to be confined to the top of the water-table range, as measured in piezometer No. 1, to the top of the clay layer which restricts vertical flow. Since the top of the water table recorded in piezometer No. 1 was $3.54 \mathrm{ft}$ above sea level on February 8, 1993 (table 5), and the top of the clay layer was $2.5 \mathrm{ft}$ below sea level, determined from cuttings collected during drilling, the area was calculated as:

$$
A=(3.54 \mathrm{ft}+2.5 \mathrm{ft}) *(\mathrm{D})=(6.04 \mathrm{ft}) * \mathrm{D}
$$

where $\mathrm{A}$ is the area of seepage, and $\mathrm{D}$ is the distance from the edge of the weir in feet (fig. 10). Using $V$ and $A$ in the equation for flow:

$$
\begin{aligned}
\mathrm{Q}=\mathrm{V} * \mathrm{~A}= & 8.8 \times 10^{-6} \mathrm{ft} / \mathrm{s} *(6.04 \mathrm{ft}) * \mathrm{D} \\
& =5.3 \times 10^{-5} \mathrm{ft}^{2} / \mathrm{s} * \mathrm{D}
\end{aligned}
$$

where $\mathrm{Q}$ is the flow rate of seepage around the west end of the Ward Lake weir. This equation assumes a constant seepage velocity when, in fact, because the watertable gradients measured decrease with distance away from the reservoir, the velocity would drop off considerably. The amount of seepage around the west end of the weir is dependant, then, on the extent to which seepage occurs beyond the edge of the weir, D. If it is assumed that all significant seepage is contained to the first $20 \mathrm{ft}$ west of the weir, then the flow rate of seepage would be:

$$
\mathrm{Q}=5.3 \times 10^{-5} \mathrm{ft}^{2} / \mathrm{s} * 20 \mathrm{ft}=0.0011 \mathrm{ft}^{3} / \mathrm{s}
$$

This estimate of seepage is useful in evaluating the extent of seepage around the west end of the weir and indicates that seepage around both ends of the weir is relatively small in comparison to the surface flow.

A study was undertaken to determine if the concrete sheet-pile weir structure had any significant leaks or cracks. On June 3, 1992, 1 gal of rhodamine dye was poured into the Ward Lake reservoir, about $5 \mathrm{ft}$ upstream of the weir. The dye was poured onto the surface and also at a depth of several feet to ensure mixing. Water samples were collected downstream of the weir at five sites, four times a day, including one site at the Braden River near Elwood Park gage. An automatic sampler placed near the middle of the weir was used to sample hourly through the night. No measurable level of dye was detected above the detection limit of $0.01 \mathrm{ppb}$. The water samples were analyzed with a portable fluorometer. The dye study was repeated on May 24-25, 1993, to confirm the 
earlier findings. Results of the study indicate that there is no significant leakage through the weir structure because no rhodamine dye was detected downstream of the weir for a 36-hour period after the dye was poured.

\section{SUMMARY AND CONCLUSIONS}

The Braden River watershed lies along the gulf coast of Florida, below Tampa Bay. Ninety percent of the watershed is located in southern Manatee County with the remaining ten percent in northern Sarasota County. The Braden River is the largest tributary to the Manatee River, which flows into Tampa Bay. The watershed lies in the coastal terraces know as the Pamlico, Talbot, Penholoway and Wicomaco Terraces of the Gulf Coast Lowlands and De Soto Plain physiographic zones. The climate is subtropical with annual average temperatures about $72{ }^{\circ} \mathrm{F}$, annual average rainfall about 56 in, and estimated annual lake evaporation 52 in. There are two dominant soil series in the watershed, the Myakka-Cassia and the EauGallie-Floridana. Both soils are found in flatwoods and are poorly drained.

Land use in the watershed is primarily urban in the western half and agricultural in the eastern half. However, the watershed is being developed for medium- to high-density housing at a rapid rate. Use of ground water is primarily for agriculture, whereas surface-water use is primarily for the city of Bradenton.

The three major aquifers underlying the watershed are the surficial, intermediate and Floridan aquifer systems. The surficial aquifer is underlaid by a clay layer that enhances the ground-water flow of the surficial aquifer to surface-water bodies. The intermediate aquifer system is confined, and has permeable zones that, at times, have high heads which indicate possible interaction with the surficial aquifer. The Floridan aquifer system also has a high head, but is confined from the surficial aquifer by the thick intermediate aquifer system.

Hydrologically, the Braden River can be divided into three distinct reaches: the lower reach, which is dominated by tides; the middle reach, which is affected by backwater from Ward Lake, and; the upper reach which is free-flowing, unaffected by backwater. There are 12 main tributaries to the Braden River examined in this study, 10 first-order and 2 second- order. Three tributaries flow into the estuary and the other nine flow into the Braden River at or above the reservoir.

A volumetric discharge method was developed so that low flow over the weir could be measured. With gage-height records of lake elevations, volumetric discharge measurements, and measurements made at high flows with standard USGS techniques, a correlation between head of water and flow was developed.

A continuous gage-height record of water level used in conjunction with the discharge rating table developed by the USGS can be used to determine the flow for the Ward Lake Outfall. From this relationship the weir coefficients for different heads of water were calculated and compared to actual field measurements. Annual mean flows for 1993 and 1994 water years were 59.7 and $57.3 \mathrm{ft}^{3} / \mathrm{s}$, respectively. Annual mean discharges are not indicative of the daily mean discharges and are heavily influenced by high-flow events.

Discharge from the Ward Lake Outfall into the estuary cannot easily be calculated using theoretical weir coefficients because of the undulating shape of the weir's crest. However, weir coefficients can be determined for the weir using direct measurements. Calculating annual mean discharge using a 1:1 ratio of annual mean discharge to drainage area, as calculated from nearby watersheds, is a reasonable way to estimate the annual mean discharge of a drainage basin.

By examining the horizontal flow around the west end of the weir, and by recording water-table elevations in piezometers, it was determined that no significant flows are seeping around the ends of the weir. A dye study investigated the possibility of leakage through the weir. No significant leakage was found.

\section{REFERENCES}

Barr, G.L., 1996, Hydrogeology of the surficial and intermediate aquifer systems in Sarasota and adjacent counties, Florida: U.S. Geological Survey Water-Resources Investigations Report 96-4063, 81 p.

Brown, D.P., 1983, Water resources of Manatee County, Florida: U.S. Geological Survey Water Resources Investigations Report 81-74, $112 \mathrm{p}$.

Camp, Dresser, and McKee, Inc., 1985, Southeast area stormwater management study: Final report: Consultant's report to the Manatee County Planning and Development Department, 111 p. 
Cherry, R.N., Stewart, J.W., and Mann, J.A., 1970, General hydrology of the Middle Gulf area: Tallahassee, Florida Bureau of Geology, Report of Investigations no. $56,96 \mathrm{p}$.

Coffin, J.E., and Fletcher, W.L., 1993, Water resources data for Florida: U.S. Geological Survey, v. 3A, Southwest Florida, $245 \mathrm{p}$.

1994, Water resources data for Florida: U.S.

Geological Survey, v. 3A, Southwest Florida, 245 p.

Conservation Consultants, Inc., 1983, Bradenton reservoir improvements, preconstruction water quality monitoring and water quality impact assessment report; Consultant's report to the city of Bradenton, $286 \mathrm{p}$.

Duerr, A.D., Hunn, J.D., Lewelling, B.R., and Trommer, J.T., 1988, Geohydrology and 1985 water withdrawals of the aquifer systems in southwest Florida, with emphasis on the intermediate aquifer system: U.S. Geological Survey Water-Resources Investigations Report 87-4259, $115 \mathrm{p}$.

Freeze and Cherry, 1979, Groundwater, Englewood Cliffs, N.J., Prentice-Hall, Inc., 604 p.

Geraghty and Miller, 1977, Groundwater resources preliminary study of the Palm Aire area, southwestern Manatee County, Florida: Consultant's report to Conservation Consultants, Inc., 30 p.

Hammett, K.M., 1992, Physical processes, salinity characteristics, and potential salinity changes due to freshwater withdrawals in the tidal Myakka River, Florida: U.S. Geological Survey Water-Resources Investigations Report 90-4054, 20 p.

Horton, R.E., 1907, Weir experiments, coefficients, and formulas: U.S. Geological Survey Water-Supply and Irrigation Paper 200, $159 \mathrm{p}$.

Hutchinson, C.B., 1984, Hydrogeology of the Verna wellfield area and management alternatives for improving yield and quality of water, Sarasota County, Florida: U.S. Geological Survey Water-Resources Investigations Report 84-4006, 53 p.

Joyner, B.F., and Sutcliffe, Horace, Jr., 1976, Water resources of the Myakka River basin area, southwest Florida: U.S. Geological Survey Water-Resources Investigations 76-58, $87 \mathrm{p}$.

King, Wisler, and Woodburn, 1948, Hydraulics (5th ed.), $169 \mathrm{p}$.

Knochenmus, L.A., and Thompson, T. H., 1991, Hydrogeology and simulated development of the brackish ground-water resources in Pinellas County, Florida: U.S. Geological Survey Water-Resources Investigations Report 91-4026, 20 p.

Kohler, M.A., Nordenson, and Baker, 1959, Evaporation maps for the United States, U.S. Weather Bureau Technical Paper 37, 13 p.

Lohman, S.W., 1972, Groundwater hydraulics: U.S. Geological Survey Professional Paper 708, 70 p.
Miller, J.A., 1986, Hydrogeologic framework of the Floridan aquifer system in Florida and in parts of Georgia, Alabama, and South Carolina: U.S. Geological Survey Professional Paper 1403-B, 91 p., 33 pls.

Mularoni, R.A., 1994a, Potentiometric surface of the Upper Floridan aquifer system, west-central Florida, May 1993: U.S. Geological Survey Open-File Report 94-32, 1 sheet.

1994b, Potentiometric surface of the Upper Floridan aquifer system, west-central Florida, September 1993: U.S. Geological Survey Open-File Report 94-81, 1 sheet.

National Oceanographic and Atmospheric Administration, 1992a, Climatological Data, Florida, June 1992, Asheville, N.C., v. 96, no. 6.

1992b, Climatological Data - Annual Summary, Florida, 1992, v. 96, no. 13.

1993, Climatological Data - Annual Summary, Florida, 1993, v. 97, no. 13.

Rantz, S.E., and others, 1982, Measurement and computation of streamflow: Volume 1- Measurement of stage and discharge, U.S. Geological Survey Water-Supply Paper $2175,284 \mathrm{p}$.

Ryder, P.D., 1985, Hydrology of the Floridan aquifer system in west-central Florida: U.S. Geological Survey Professional Paper 1403-F, 63 p.

Southeastern Geological Society, Ad hoc committee, compilers, 1986, Hydrogeologic units of Florida: Tallahassee, Florida Geological Survey Special Publication no. 28, $9 \mathrm{p}$.

Southwest Florida Water Management District, 1990 GIS data base.

Tampa Bay Regional Planning Council, 1986, Water quality studies of the Anclote and Braden Rivers: Tampa, Fla., $133 \mathrm{p}$.

University Press of Florida, 1994, Florida Statistical Abstract (28th ed.): $794 \mathrm{p}$.

U.S. Department of Agriculture, 1983, Soil survey of Manatee County, Florida: Soil Conservation Service, 159 p. -1987, Soil survey of Sarasota County, Florida: Soil Conservation Service: $147 \mathrm{p}$.

U.S. Department of Commerce, 1964, Weather Bureau Technical Paper 49, 29 p.

Wanalista, M. P., 1989, Evers Reservoir hydrologic study: Orlando, University of Central Florida, 139 p.

White, W.A., 1970, The geomorphology of the Florida Peninsula: Tallahassee, Florida Bureau of Geology Bulletin 51, $164 \mathrm{p}$. 